Original Research Paper

\title{
Finite Element Evaluation of RC Frames Strengthened with FRPs under Fire and Lateral Loads
}

\author{
${ }^{1}$ Reza Salehi" and ${ }^{2}$ Abbas Akbarpour \\ ${ }^{1}$ South Tehran Branch Islamic Azad University, Tehran, Iran \\ ${ }^{2}$ Department of Civil Engineering, South Tehran Branch Islamic Azad University, Tehran, Iran
}

\author{
Article history \\ Received: 22-07-2020 \\ Revised: 28-08-2020 \\ Accepted: 26-09-2020 \\ Corresponding Author: \\ Reza Salehi \\ South Tehran Branch Islamic \\ Azad University, Tehran, Iran \\ Email:st_r.salehi@azad.ac.ir
}

\begin{abstract}
Reinforced concrete is one of the most common structures in the world. These structures may be under extreme loading conditions such as earthquake or they may confront with other flooding, impact or even the fire load. In the term of fire load, RC structures are very sensitive and due to the brittle behavior, the fast collapsing happens. In this research, two experimental setups are validated: (1) RC frame and (2) RC column. The Reinforced Concrete (RC) frame is modeled using finite element ABAQUS software and validated with experimental program. The RC frame validation is subjected to lateral and vertical loads. On the other side, RC column is also modeled and validated using ABAQUS software. The RC column is subjected to fire load. The results of validations show that the simulation techniques are accurate to perform the further investigation. The RC frames are retrofitted by FRP sheets and reinforced using steel or FRP bars. The angle of FRP sheets is both convergent and divergent. The fire is applied at the inside surface of the frame by $200,400,600,800$ and $1000^{\circ} \mathrm{C}$ and lateral displacement-control load is considered, concurrently. Forcedisplacement diagrams have been evaluated to check the load capacity, ductility, stiffness, seismic factor and crack propagations. The results show that using FRP has better performance at the lower fire temperature.
\end{abstract}

Keywords: Reinforced Concrete (RC) Frame, Fire and Displacement Loading, FRP Bars and Sheets, Finite Element Method

\section{Introduction}

The structures are encountered with natural problems such as earthquake, flooding and specially, extreme loading conditions. In fact, the structural elements may be affected by fire or impact loading or the simultaneous loads of earthquake and fire in disastrous manner. According to disastrous events during the last two decades like fire and explosion, the necessity of strengthening of structures plays a vital role. So, understanding the structural behavior and damage criteria of the existing structures can be useful to avoid collapsing and improve their capability (Fallahi et al., 2019; 2018; Maranan et al., 2016; Soleimani and Sayyar Roudsari, 2015; Soroushnia et al., 2011; Xiao et al., 2016). There are many studies for evaluating RC structures under extreme loading conditions like fire, air blast and so on.

Kodur et al. (2003) performed an experimental study on five different concrete columns under fire loading condition. The investigated cases were Normal Strength Concrete (NSC) and High Strength Concrete (HSC) by using steel and polypropylene fibers. The results showed that the column with NSC material had better performance. Also, using polypropylene fibers could increase the ductility and load capacity. In this case, the load capacity of HSC columns was higher than columns with normal concrete. Anil and Altin (2007) had experimental investigation on infilled RC frames. The aim of their research was to find out the ductility behavior of RC frames under lateral cyclic loading. Nine one-story RC frames were tested in the laboratory under cyclic loading conditions. They casted one RC frame without infilled part called bar frame and eight other frames were infilled. The results showed that infilled frame had brittle behavior than bar frame. However, the initial stiffness and energy absorption of infilled frames is higher than bar frame. Also, the larger aspect ratio of infilled frame causes increasing lateral strength of infilled RC frame. Moreover, infilled RC frames have more stiffness and load capacity than simple frames. AlKamaki et al. (2015) studied on circular cross-section RC columns damages under temperature loading 
conditions. Twenty large size RC columns with $750 \times 204$ millimeters in dimensions, were tested. Six of those columns were considered as control group and fourteen columns were heated fewer than $30 \%$ of maximum load. Also, eight of these columns were wrapped using Carbon Fiber Reinforced Polymer (CFRP). The results showed that using CFRP sheets can increase the durability of RC columns after 600,800 and $1000^{\circ} \mathrm{C}$. Some of the researches indicated the effect of extreme loading conditions in normal RC members and investigated any deterioration and defects inside or on the surface of the concrete (Goldston et al., 2016; Pham and Hao, 2016; Sayyar Roudsari et al., 2019a; 2019b; 2019c; 2020a; Soleimani et al., 2019; Soleimani and Sayyar Roudsari, 2019; Tang and Saadatmanesh, 2003). However, different studies also undertook to find out the effect of HSC and high-performance materials under fire condition. These studies were done by applying different fire temperatures in various elements (Baant et al., 1996; Hamoush et al., 2019; Khaliq and Kodur, 2011; 2013; Kodur and Sultan, 1998). Gyu-Yong et al. (2009) studied on the behavior of $\mathrm{HSC}$ under $700^{\circ} \mathrm{C}$ to find out the effect of fire resistance of concrete. The results showed that the concrete strength reduced significantly after $400^{\circ} \mathrm{C}$. The reduction of module of elasticity also was evaluated under different temperature loading conditions (Castillo, 1987; Persson, 2004). Tan and Nguyen (2013) investigated RC columns under the combination of uniaxial eccentricity and temperature loading conditions. The authors used 29 and $55 \mathrm{MPa}$ of compressive strength of concrete to test under elevated temperature. The RC column had a square cross-section of 300 and $3300 \mathrm{~mm}$ height. The results showed that applying simultaneous uniaxial eccentricity and temperature loads caused the faster failure of concrete. Roudsari and Abu-Lebdeh (2019) did analytical study on the effect of fire temperature loading (ASTM, 1990) time on reinforced concrete column behavior. His results show that by increasing the time of fire load, the stiffness is reduced.

This paper focuses on RC frame under concurrent fire and lateral loading conditions. Two different validation of models are done: One as a frame without fire load and others as a sample with fire load. Different variables such as the type of material of bars like steel and Carbon Reinforced Polymer (CFRP) as well as the retrofitting pattern are used as the convergent or divergent angle. The pattern of wrapping is the state-of-the-art method is this research. Beside the fire and lateral load, the pressure load is applied on the beam, too. Different target temperatures are used including 200, 400, 600, 800 and $1000^{\circ} \mathrm{C}$. The models are 5 control samples, 15 retrofitted models with CFRP sheets and 11 reinforced models with CFRP bars. The FRP sheet's angles are 0, 45 and 90 degrees for beam and columns. In this research, ABAQUS software is used. The Concrete Damage Plasticity Model
(CDPM) is used in order to define compressive strength, tensile strength and its damage parameters. The numerical results showed very good agreement with experimental output. This paper provides information as load capacity, ductility, stiffness regarding the effect of fire load and retrofitting method of these elements.

\section{Materials and Methods}

In order to use ABAQUS software, the validation of FEM with an experimental program is essential. In this study the experimental test performed by (Hemmati et al., 2016) is considered. In this research, two different concrete compressive strengths are used; at first a High-Performance Fiber Reinforced Cementitious Composite (HPFRCC) with $24 \mathrm{MPa}$ used for beamcolumn joint-connection and $48 \mathrm{MPa}$ as normal concrete for other section areas. The geometry and reinforcement details are shown in Fig. 1 and 2. Also, the loading conditions of experimental set up can be seen in the original article.

In this section, the concrete parameters are defined using the work performed by (Roudsari et al., 2019; Sayyar Roudsari et al., 2018). They used MATLAB toolbox to compute different concrete parameters including compressive and tensile strain- stress and the corresponding damages. In research conducted by (Roudsari et al., 2019), he developed a model to employ the compressive strength and the failure strain of concrete. In this regard, the strain rate increment is computed based on division of failure strain to small number. Sayyar Roudsari et al. suggested the small number should be at least one-tenth of failure strain. In this step, the number of increments can be calculated. Then, the elastic and plastic strains are computed in both tensile and compressive. After computing the strains, the corresponding stresses are computed. In this step, the linear and nonlinear should be separated. Because, based on his novel theory, concrete damage plasticity model of ABAQUS should use the plastic side of stress-strain data. In order to adjust the boundary, $45 \%$ of compressive stress is considered. After modifying and generating the plastic stress-strain data, the damage parameters of tensile and compressive sides are also computed. These parameters can be used in ABAQUS software. The ABAQUS input data for 24 and $48 \mathrm{MPa}$ is shown in Fig. 3 (Roudsari et al., 2019).

The material properties of steel bars as the yield stress, module of elasticity and ultimate strain are reported 400 $\mathrm{MPa}, 200 \mathrm{GPa}$ and 14.5\%, respectively (Obaidat et al., 2010). The CFRP sheets for retrofitting of the RC frame is one layer with $2 \mathrm{~mm}$ thickness. The ultimate tensile stress $\left(f_{f u}\right)$ of CFRP and elasticity modulus are $3500 \mathrm{MPa}$ and $230 \mathrm{GPa}$, respectively and the width of sheet is $150 \mathrm{~mm}$. The CFRP mechanical properties are demonstrated in the 
Table. 1. The mechanical properties of CFRP bars are $2900 \mathrm{MPa}$ and $300 \mathrm{GPa}$ (as ultimate stress and module of elasticity, respectively).
The fire criteria are considered by ASTM E119 standard (ASTM, 1990) to define the temperature-time amplitude (Fig. 4).

Table 1: Mechanical properties of CFRP Layers (Kheyroddin and Naderpour, 2008)

\begin{tabular}{llllll}
\hline $\begin{array}{l}\text { Tensile strength } \\
\text {-parallel of layer } \\
\text { direction }(\mathrm{MPa})\end{array}$ & $\begin{array}{l}\text { Compressive strength } \\
- \text { parallel of layer } \\
\text { direction }(\mathrm{MPa})\end{array}$ & $\begin{array}{l}\text { Tensile strength } \\
\text {-perpendicular of } \\
\text { layer direction }(\mathrm{MPa})\end{array}$ & $\begin{array}{l}\text { Compressive strength } \\
- \text { perpendicular of } \\
\text { layer direction }(\mathrm{MPa})\end{array}$ & $\begin{array}{l}\text { longitudinal } \\
\text { shear strength } \\
(\mathrm{MPa})\end{array}$ & $\begin{array}{l}\text { Transvers } \\
\text { shear strength } \\
(\mathrm{MPa})\end{array}$ \\
\hline 3500 & 1985 & 133 & 536 & $' 117 / 4$ & $117 / 4$
\end{tabular}

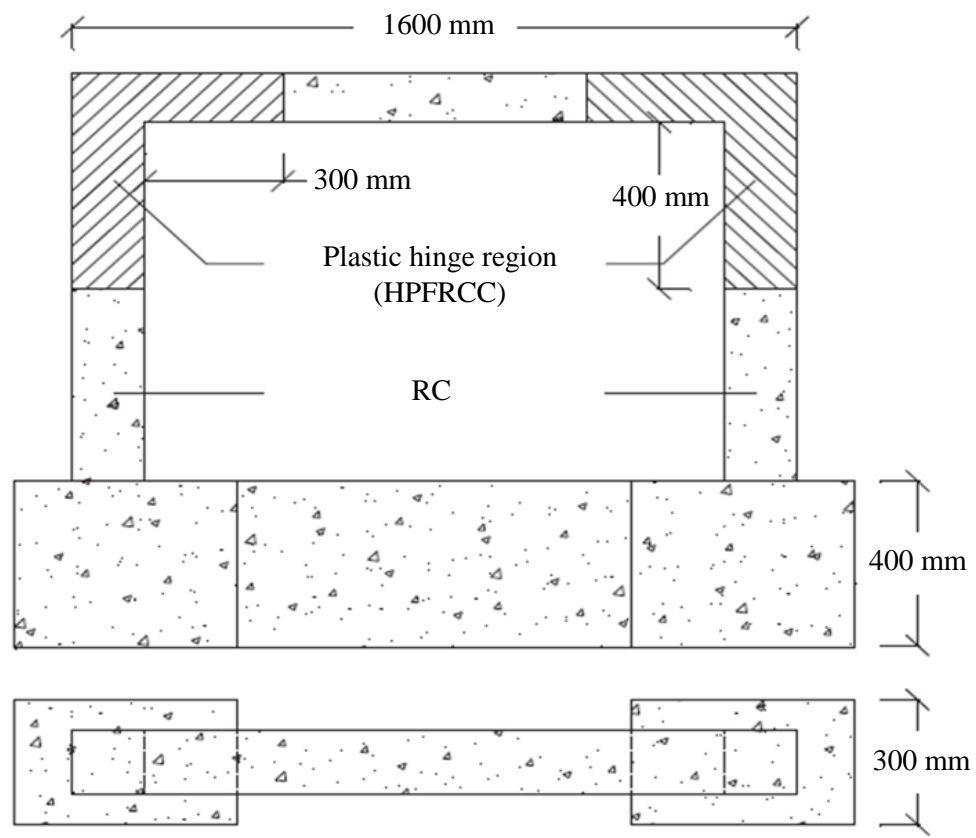

Fig 1: Geometry details of RC frame

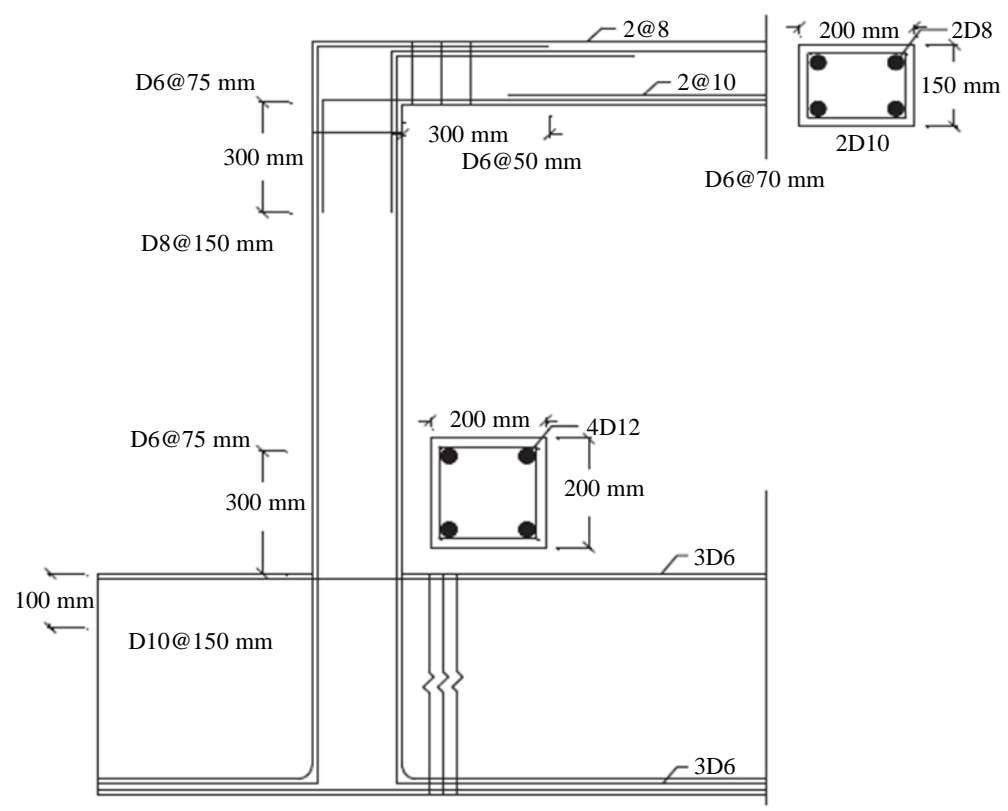

Fig 2: Reinforcement details of RC frame 
Reza Salehi and Abbas Akbarpour / American Journal of Engineering and Applied Sciences 2020, 13 (3): 584.601 DOI: 10.3844/ajeassp.2020.584.601
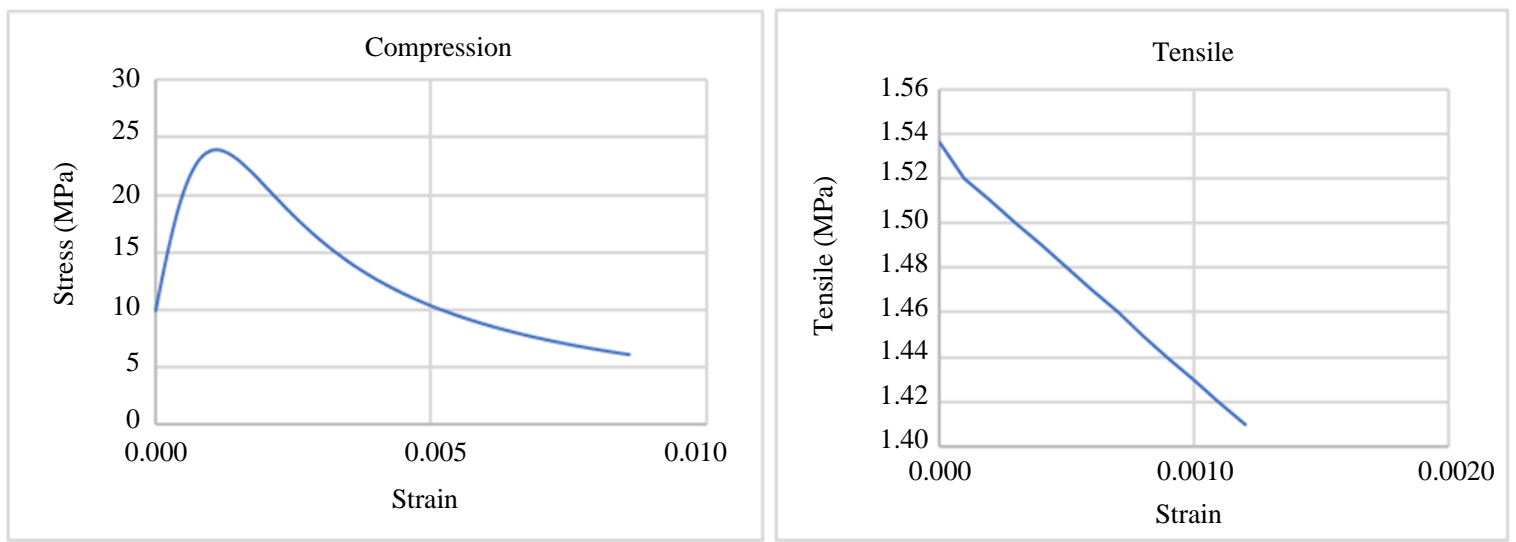

(a)
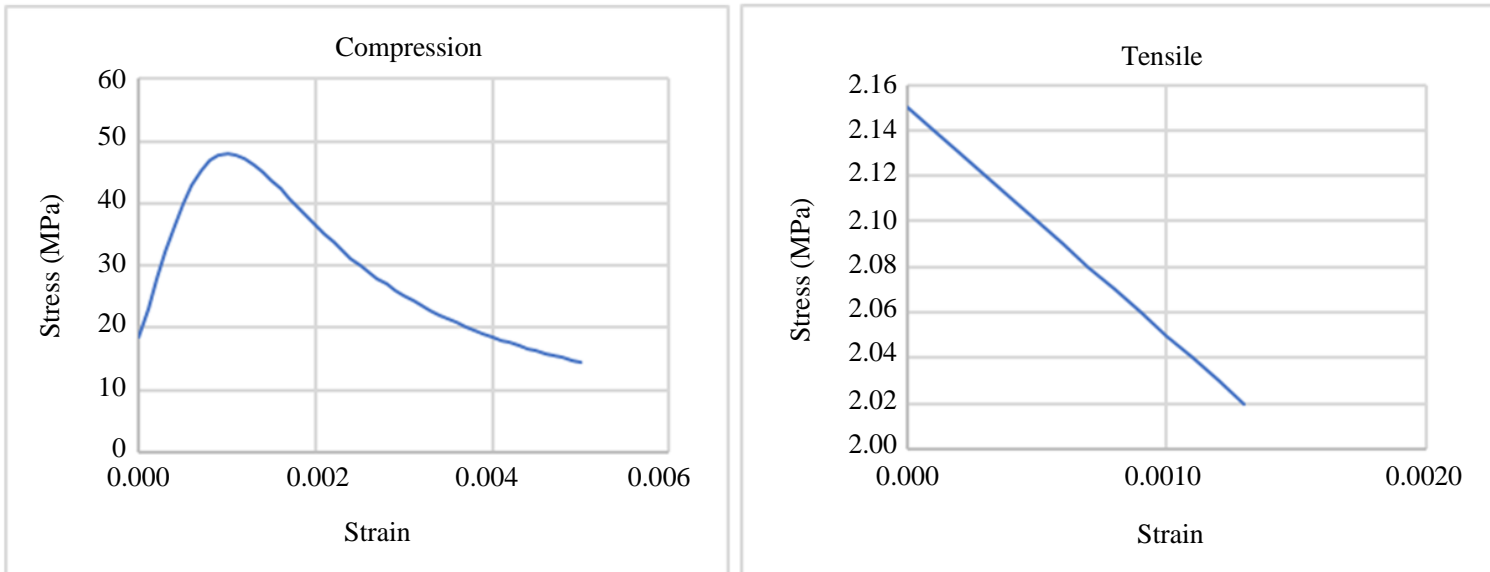

(b)

Fig. 3: Concrete Compressive and Tensile Stress-Strain for (a) $24 \mathrm{MPa}$ (b) $48 \mathrm{MPa}$

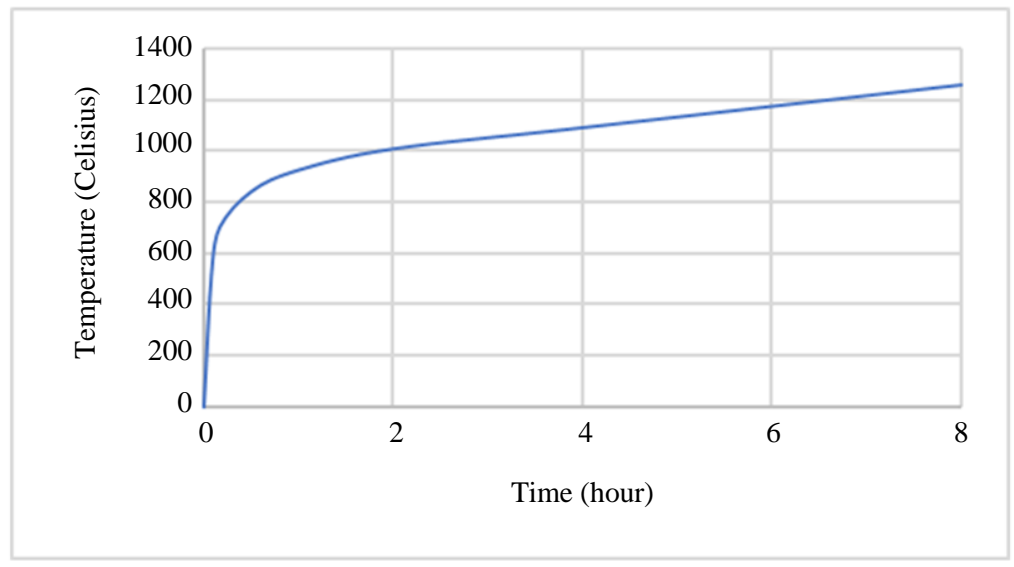

Fig 4: Time-Temperature Diagram (ASTM, 1990)

\section{Finite Element Modeling and Validations}

To validate by ABAQUS software, we selected two experimental. These validations include a frame without fire loading and a sample under fire loading. The first validation considers the $\mathrm{RC}$ frame without fire load. The modeling of RC frame is based on (Hemmati et al., 2016) using ABAQUS software. The C3D8R (8-node element using reduced integration) is used for modeling of the frame, S4R and Truss element (T3D2) are 
employed for CFRP sheets and modeling of bars and stirrups. The Embedded Region Coupling has been utilized to create bonding conditions between bars and concrete elements. The interaction between CFRP sheets and concrete surface is subjected to Tie interaction. The interaction modeling is shown in Fig. 5a. The NonLinear General Static analysis is used for modeling of $\mathrm{RC}$ frame. This RC frame is without fire load. The boundary conditions are divided into two different loading categories. The first load is pressure loading (at the center-top of the beam). The lateral load is applied using displacement-control by defining the Displacement/Rotation category. U1, U2 are fixed and U3 is released. This issue is taken into account by defining a Set of Nodes using ABAQUS tools. The bottom surface of slab is pinned (U1, U2 and $\mathrm{U} 3=0$ ). The lateral constant load and pressure are considered $65.5 \mathrm{~mm}$ and $1 \mathrm{MPa}$, respectively. Figure $5 \mathrm{~b}$ shows the boundary conditions of RC frame.

After analysing the RC frame, the shear forcedisplacement diagram is carried out. This validation is shown in Fig. 6. According to Fig. 6, the FEM modeling has a very good accuracy with experimental tests. By comparing the maximum load capacity, it can be declared that the maximum load capacity in laboratory is $65.31 \mathrm{kN}$ while this parameter is $65.25 \mathrm{kN}$ in ABAQUS (the difference is just about $0.01 \%$ ).

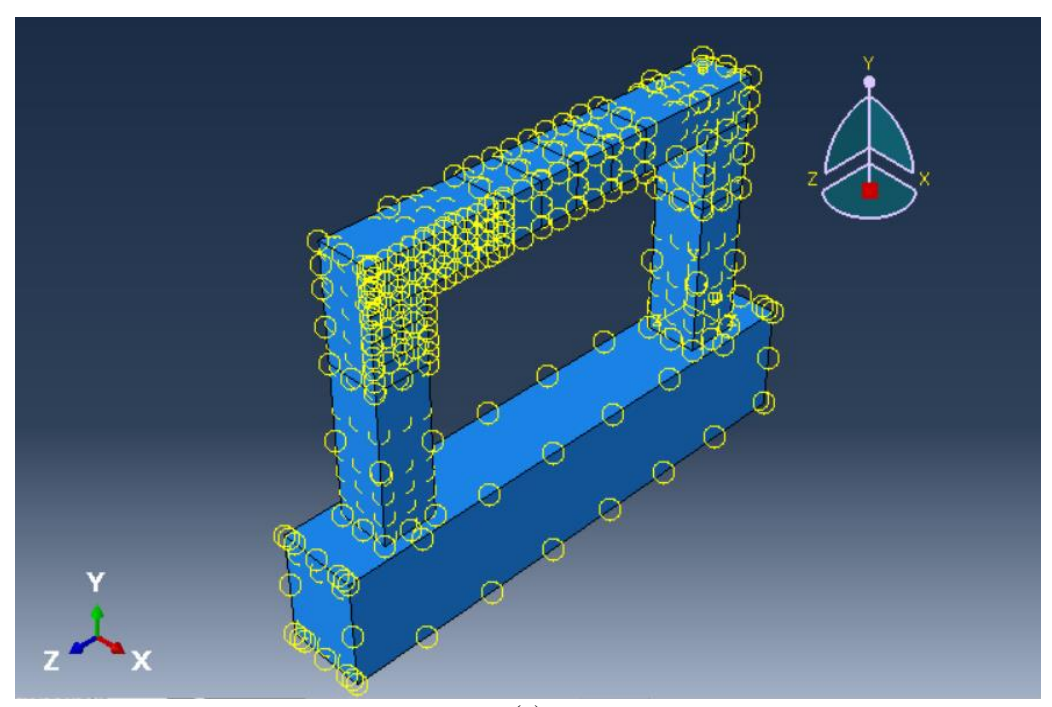

(a)

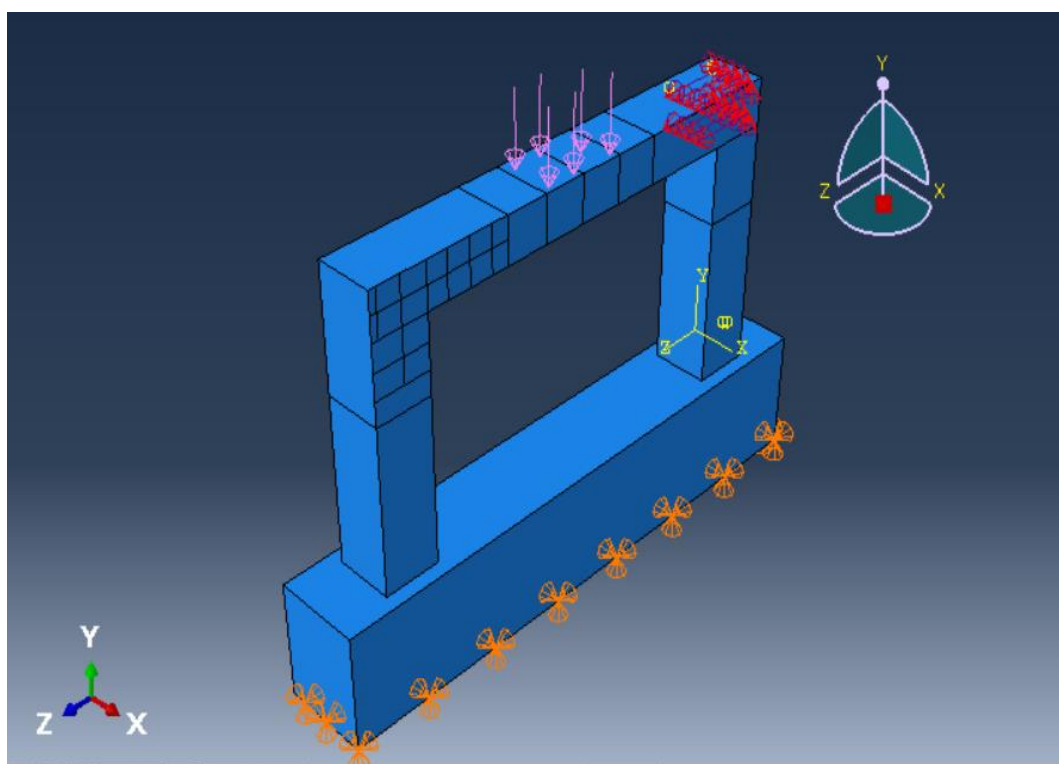

(b)

Fig. 5: The ABAQUS model (a) Interaction Modeling (b) Boundary Conditions 


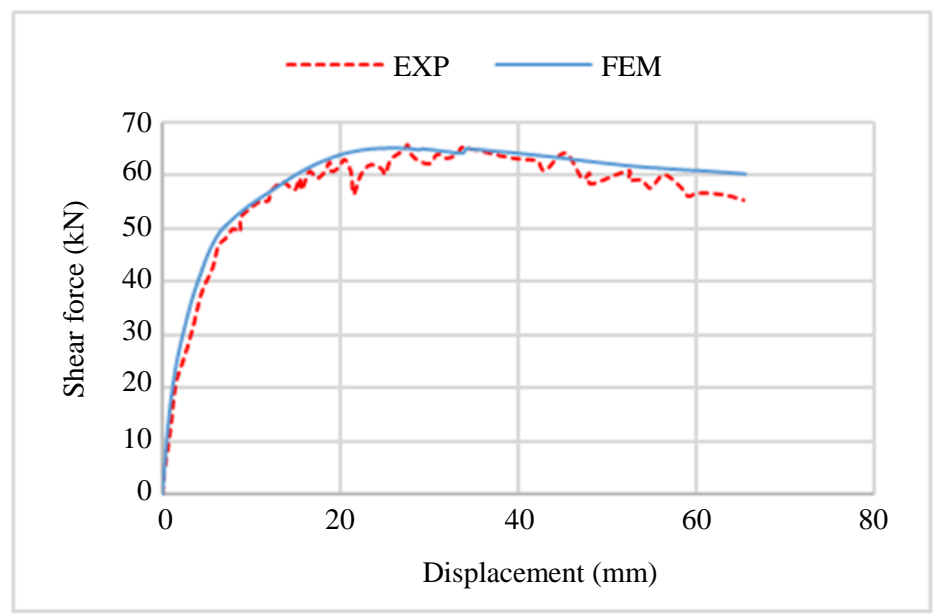

Fig. 6: Validation of Experimental test - versus ABAQUS Software - Without Fire Load

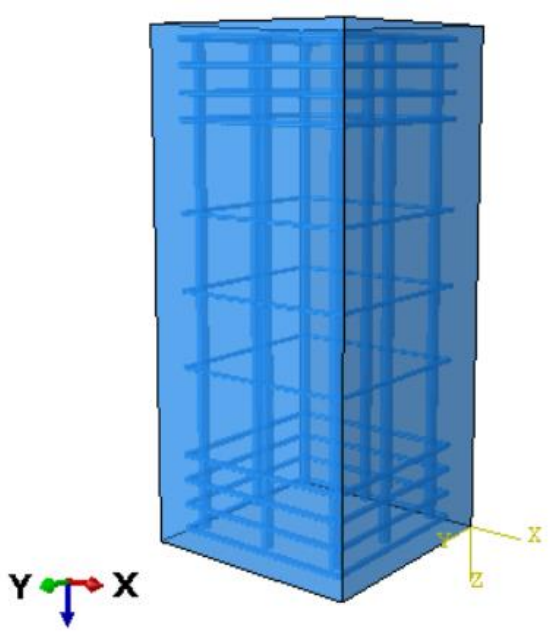

Fig. 7: RC Column modeling under both fire and lateral load

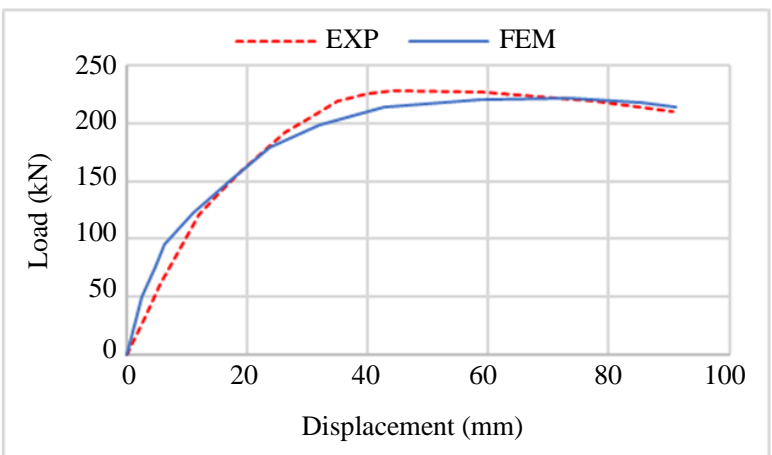

Fig. 8: Validation RC Column -Experimental test versus ABAQUS - under both Fire and Lateral Load

The second validation is based on (Zhang et al., 2017). He did experimental study on the RC column under fire and earthquake loading conditions. The column geometry was $350 \times 350 \mathrm{~mm}$ with 8 longitudinal bars with $20 \mathrm{~mm}$ diameters and transvers bar with 10 $\mathrm{mm}$ diameter. The lateral load was applied by displacement control up to $600 \mathrm{~mm}$ as cyclic load and the fire temperature was considered based on ISO-834 standard fire curve. The maximum furnace temperature of this experimental study reached $900^{\circ} \mathrm{C}$. Figure 7 shows the modeling of the RC column by ABAQUS. The results of experimental test and finite element modeling are shown in Fig. 8. The load-displacement diagram indicates very good agreement of fire modeling by ABAQUS (about 2\% differences). In other word, the finite element output is about $214 \mathrm{kN}$ while the experimental result is $210 \mathrm{kN}$.

\section{Parametrical Study}

In this section, a parametrical study under temperature analysis is developed. The RC frame is used for analysing under $200,400,600,800$ and $1000^{\circ} \mathrm{C}$. The frames are divided into three different groups. The first group is RC frames using only steel rebars under temperature analysis. The second group regards the same frames retrofitted by CFRP sheets. The third group is considered by reinforcing the frames with CFRP bars. For modeling of frames using CFRP bars, the reinforcing is done by; firstly, the longitudinal bars of the beam are just CFRP bars and steel bars are used for members (column, slab). Secondly, all longitudinal bars in both beam and column are reinforced by CFRP bars. Figure 9 shows the geometry shape and details of retrofitting by CFRP wrapping. As it can be seen in Fig. 9, the layout angle of CFRP is different in the beam and columns. The method of retrofitting is shown as model 1, model 2 and model 3. These models have specific configurations which are shown in Fig. 9. It should be noted that the layout direction is divergent. In other word, looking to 
Fig. 9 and for example the model 1, the left and right columns have divergent layout direction. Moreover, in models 2 and 3, the same concept is considered. In the Table 2 the description of wrapping and reinforcing models by CFRP is shown. It should be noted that the model's name with steel bars under temperature analysis is called $\mathrm{M} 200\left(200^{\circ} \mathrm{C}\right), \mathrm{M} 400\left(400^{\circ} \mathrm{C}\right), \mathrm{M} 600\left(600^{\circ} \mathrm{C}\right)$, $\mathrm{M} 800\left(800^{\circ} \mathrm{C}\right)$ and $\mathrm{M} 1000\left(1000^{\circ} \mathrm{C}\right)$.

Table 2: Models Description Details and Names

\begin{tabular}{ll}
\hline M-0 & Reinforced by steel bars without temperature loading \\
\hline M-200 & Reinforced by steel bars under 200 Celsius degree loading \\
M-400 & Reinforced by steel bars under 400 Celsius degree loading \\
M-600 & Reinforced by steel bars under 600 Celsius degree loading \\
M-800 & Reinforced by steel bars under 800 Celsius degree loading \\
M-1000 & Reinforced by steel bars under 1000 Celsius degree loading \\
FC-C45B90 & Strengthening with CFRP, Column 45-degree, Beam 90 degree \\
FC-C45B45 & Strengthening with CFRP, Column 45-degree, Beam 45 degree \\
FC-C0B45 & Strengthening with CFRP, Column 0-degree, Beam 90 degree \\
F-CB-Total & Reinforcing by CFRP bars in both Beam and Column \\
F-CB-Beam & Reinforcing by CFRP bars in the Beam \\
F-CB-Beam-Bot & Reinforcing by CFRP bars in the Tensile zone of the Beam \\
\hline
\end{tabular}

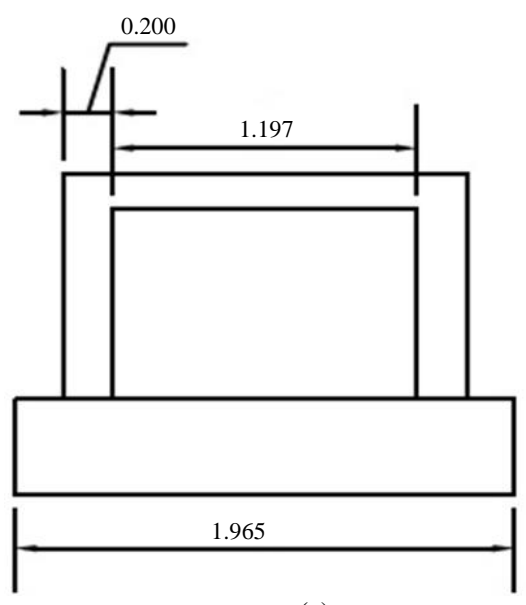

(a)

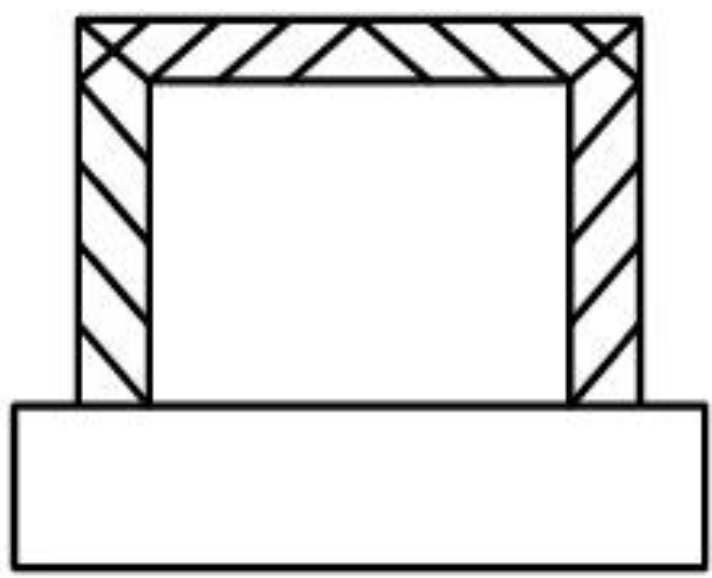

(c)

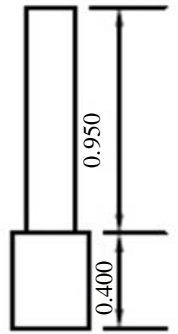

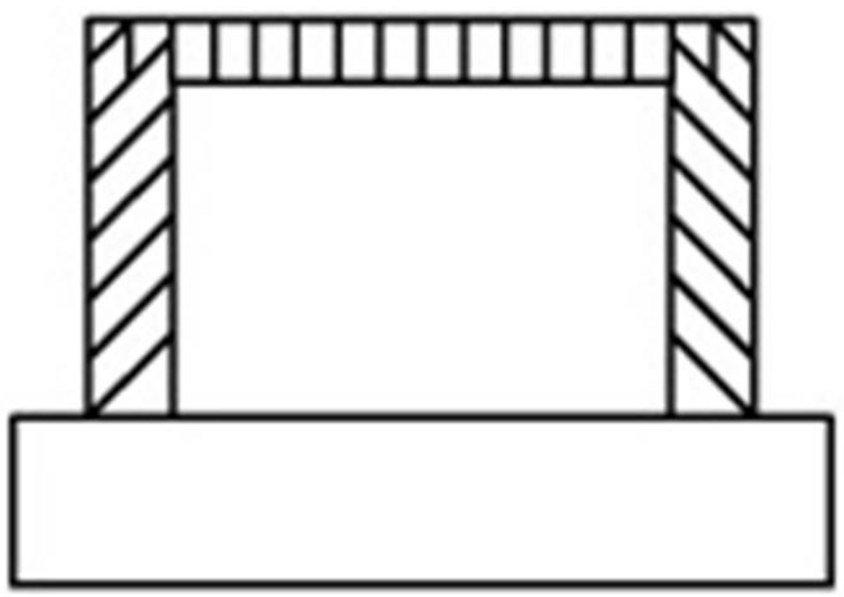

(b)

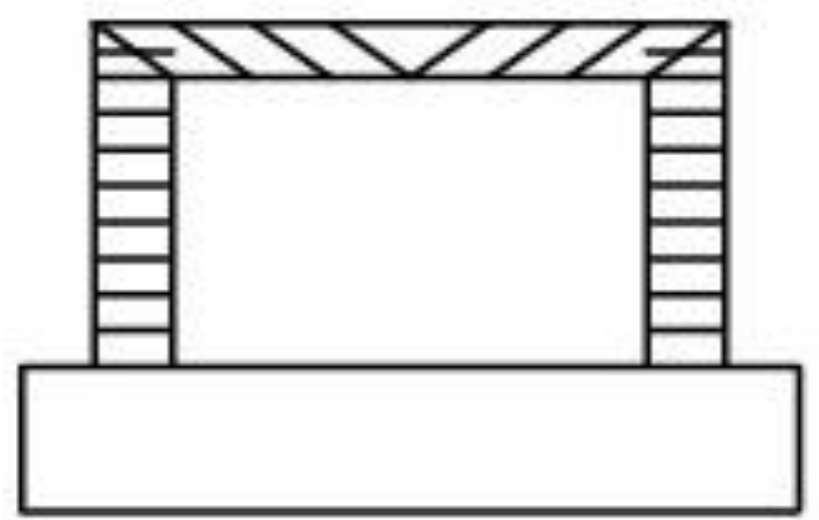

(d)

Fig. 9: Geometry Details of Retrofitting distribution of RC Frame (a) Original RC Frame (b) Model 1; the layout direction for column and beam is 45 and 90 degree, respectively (c) Model 2; the layout direction for column and beam is 45 degrees (d) Model 3; the layout direction for column and beam is 0 and 45 degree, respectively 
In order to apply the fire load in these models, the same features of first validation model (RC frame) are considered and some other fire load criteria are applied as the Temperature-Dependent Data is provided. The initial fire temperature is zero and the maximum target one depends upon the fire temperature, for instance at $200^{\circ} \mathrm{C}$, it should be 200 . Also, the Specific Heat is considered 5700 for bars, 6000 for CFRP sheets and 1000 for concrete using Constant Volume criteria. The range of conductivity for FRP bars and layout are 0.0030.0057 and $0.035-0.006$, respectively. The conductivity for steel bars is $0.04-0.0518$ and the specific heat is 5255. The conductivity parameters for concrete is 0.0005-0.00114. The Hashin Damage parameters are used to define the tensile and compressive behavior of FRP layout (the longitudinal tensile strength is 1278 $\mathrm{MPa}$ and its elasticity modulus is $46000 \mathrm{MPa}$ ). In terms of fire analysis, the Coupled Temp-Displacement
(Transient) Analysis is used to apply for simultaneous fire and lateral displacement. It should be noted that, the time of fire depends on the amount of temperature. Figure 10 shows the time-amplitude of temperature analysis.

Also, the Max Allowable Temperature Change Per Increment is applied $10^{\circ} \mathrm{C}$. In the interaction module, the Surface Film Condition as the Film Coefficient and Sink Temperature are considered 0.01 and 25 , respectively. The lateral and pressure loading are considered as the same as validation model. In the loading module also, the Predefined Field is created to make environment temperature of Concrete Frame by applying $25^{\circ} \mathrm{C}$. The fire load is utilized by choosing Other/Temperature from Boundary Condition, applying at the inside surface of frame. Each temperature has its own amplitude using Fig. 10. Also, the Heat Flux is applied "10"for all elements (Sayyar Roudsari et al., 2020b).

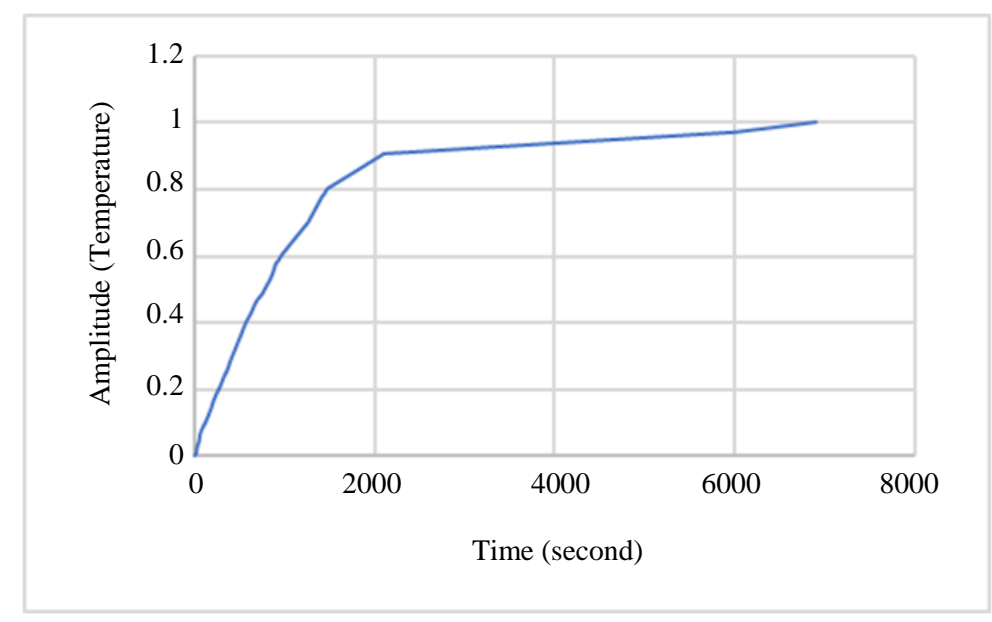

Fig. 10: Time-amplitude changes (ASTM, 1990)

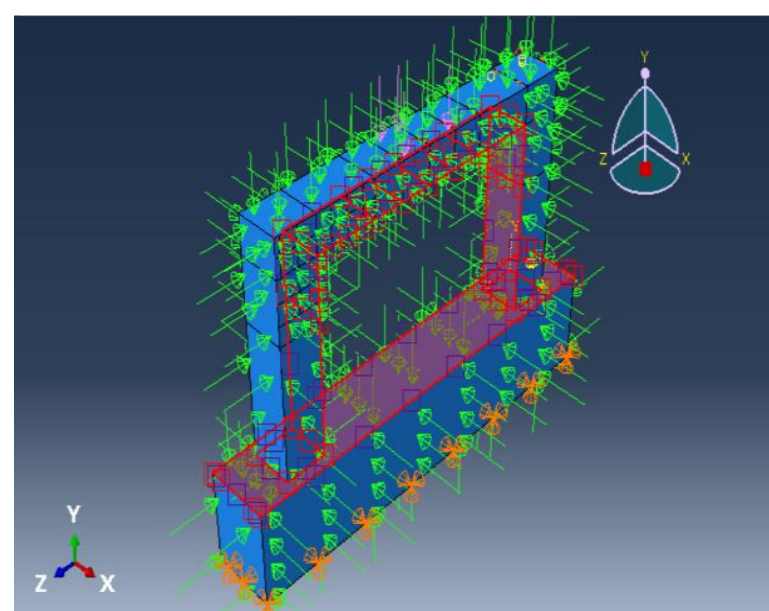

(a)

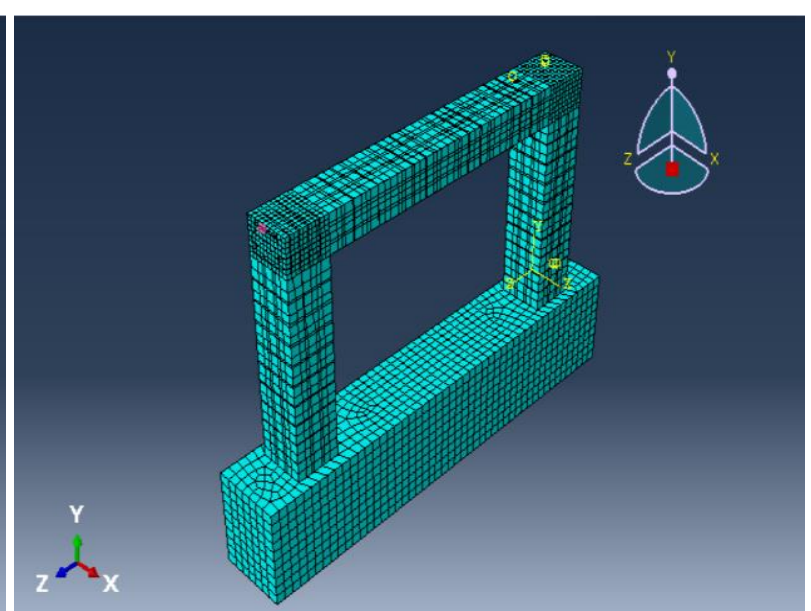

(b)

Fig. 11: The ABAQUS model (a) temperature, pressure and lateral displacement loading conditions (b) meshing 
Figure 11a demonstrates the temperature, pressure and lateral displacement loading conditions of $\mathrm{RC}$ frame. Eventually, in the term of meshing criteria, the mesh study is used to verify the mesh seed size. Also, the Mesh Type is Coupled-Temperature-Displacement (Fig. 11b).

\section{Results and Discussion}

In this section, the results of RC frames are discussed. The RC frame is evaluated under 200, 400, 600,800 and $1000^{\circ} \mathrm{C}$. Then, the $\mathrm{RC}$ frame is reinforced by CFRP bars under the same loading temperature conditions and eventually, the RC frames are strengthened using CFRP sheet. The load-displacement diagrams are evaluated in this section by considering the load capacity, ductility, energy absorption and stiffness. The load-displacement diagram shows in Fig. 12 is regarding the RC frame models without and with fire loading condition. It should also be noted that these samples are modeled using only steel bars. The model's name indicates the fire loading; as an illustration, M-200 means $200^{\circ} \mathrm{C}$ applied as fire temperature and so on.

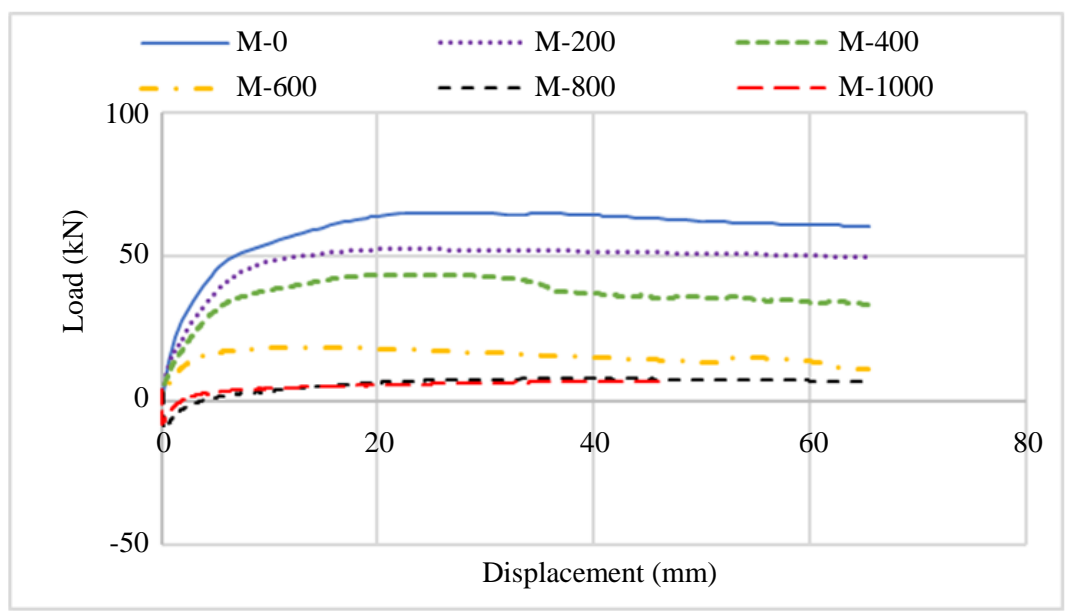

Fig. 12: Load displacement diagram for model with steel bars under different temperature loading

\begin{tabular}{|c|}
\hline $\begin{array}{l}\text { S, S33 } \\
\text { (Avg: 75\%) }\end{array}$ \\
\hline $\begin{array}{l}+2.215 \mathrm{e}+00 \\
-7.461 \mathrm{e}-01\end{array}$ \\
\hline $\begin{array}{l}-3707 e+00 \\
-6.668 e+00\end{array}$ \\
\hline$-9.629 \mathrm{e}+00$ \\
\hline$-1.259 \mathrm{e}+01$ \\
\hline $\begin{array}{l}-1.555 \mathrm{e}+01 \\
-1.851 \mathrm{e}+01\end{array}$ \\
\hline $\begin{array}{l}-1.851 \mathrm{e}+01 \\
-2.147 \mathrm{e}+01\end{array}$ \\
\hline$-2.444 \mathrm{e}+01$ \\
\hline $\begin{array}{l}-2.740 e+01 \\
-3.036 e+01\end{array}$ \\
\hline$-3.332 \mathrm{e}+01$ \\
\hline
\end{tabular}
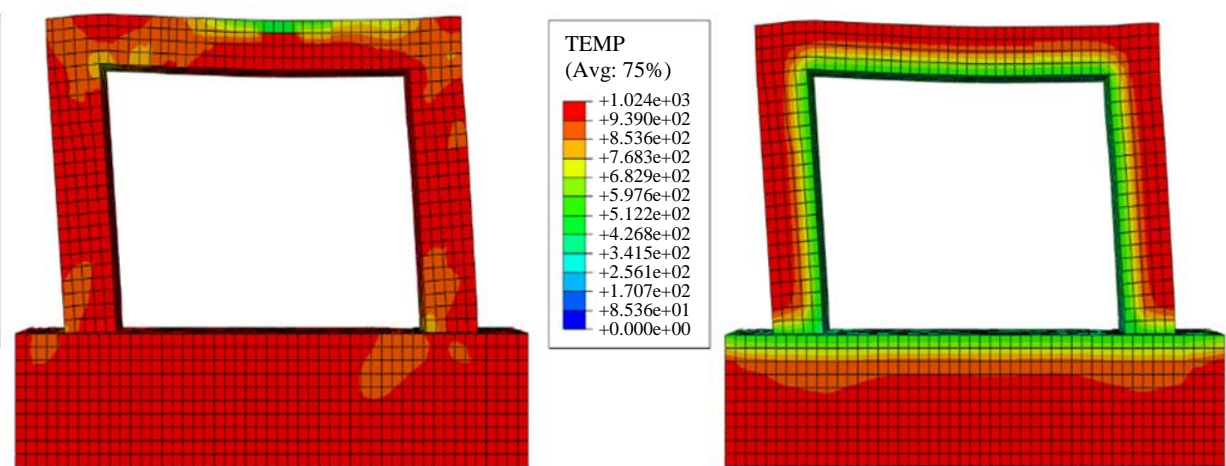

\begin{tabular}{|l|}
\hline S, Mises \\
$($ Avg: $75 \%)$ \\
\\
$+4.000 \mathrm{e}+02$ \\
$+3.667 \mathrm{e}+02$ \\
$+3.333 \mathrm{e}+02$ \\
$+3.000 \mathrm{e}+02$ \\
$+2.667 \mathrm{e}+02$ \\
$+2.333 \mathrm{e}+02$ \\
$+2.000 \mathrm{e}+02$ \\
$+1.667 \mathrm{e}+02$ \\
$+1.333 \mathrm{e}+02$ \\
$+1.000 \mathrm{e}+02$ \\
$+6.667 \mathrm{e}+01$ \\
$+3.334 \mathrm{e}+01$ \\
$+5.695 \mathrm{e}-03$ \\
\end{tabular}

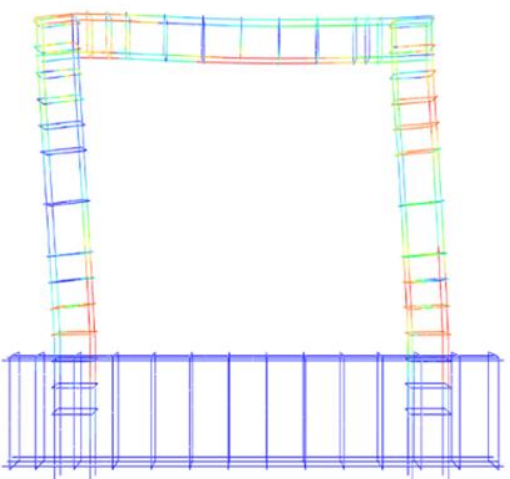

(a) 
Reza Salehi and Abbas Akbarpour / American Journal of Engineering and Applied Sciences 2020, 13 (3): 584.601 DOI: 10.3844/ajeassp.2020.584.601
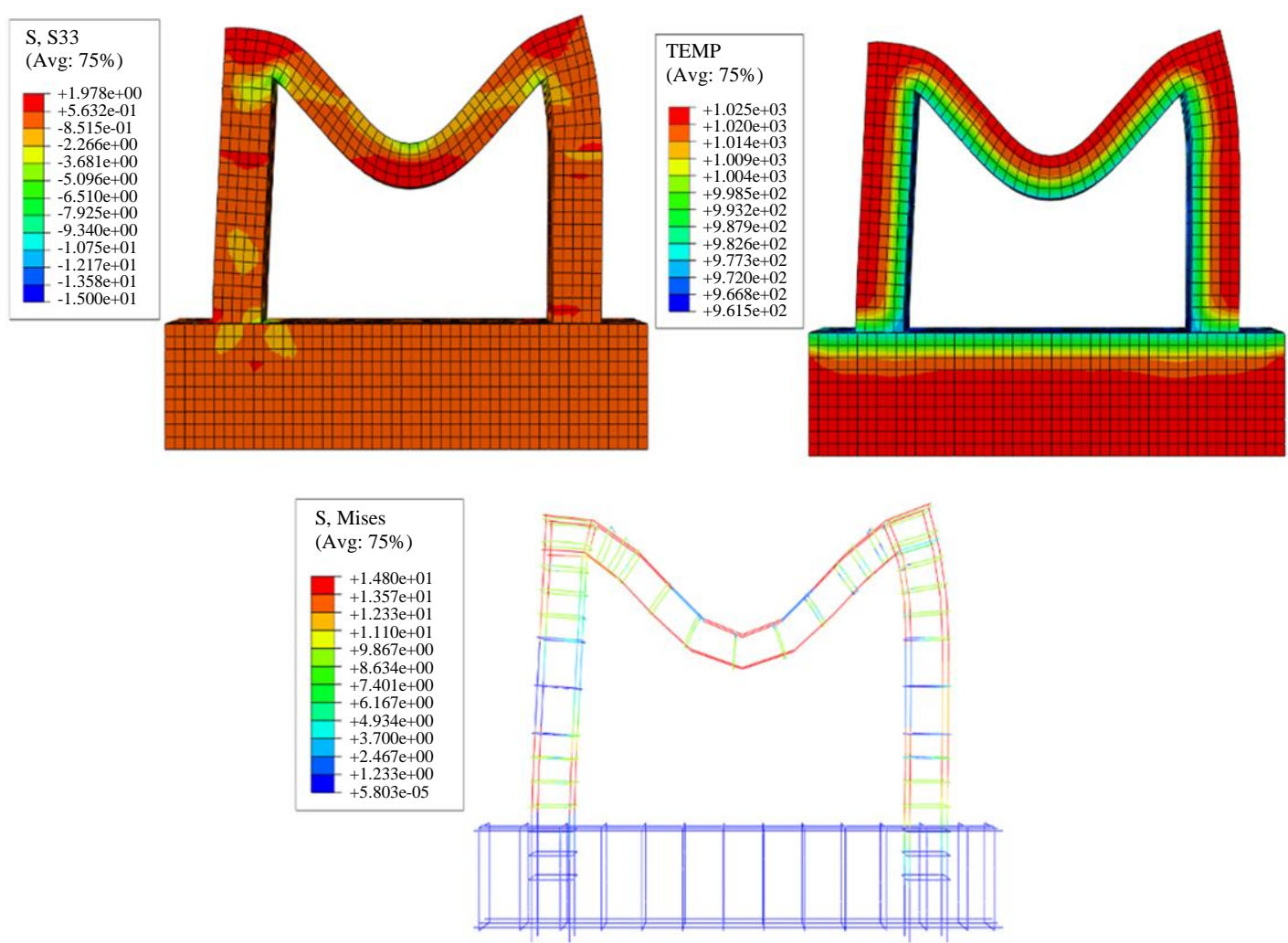

(b)

Fig. 13: Von Misses and Temperature Stress Distribution of (a) M200 (b) M-1000

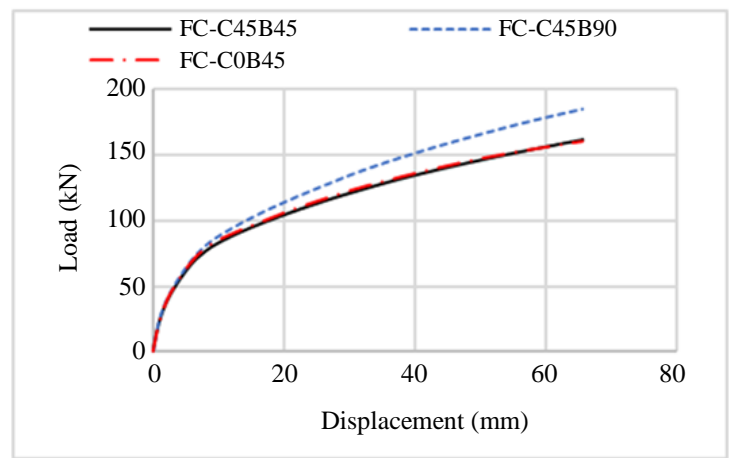

(a)

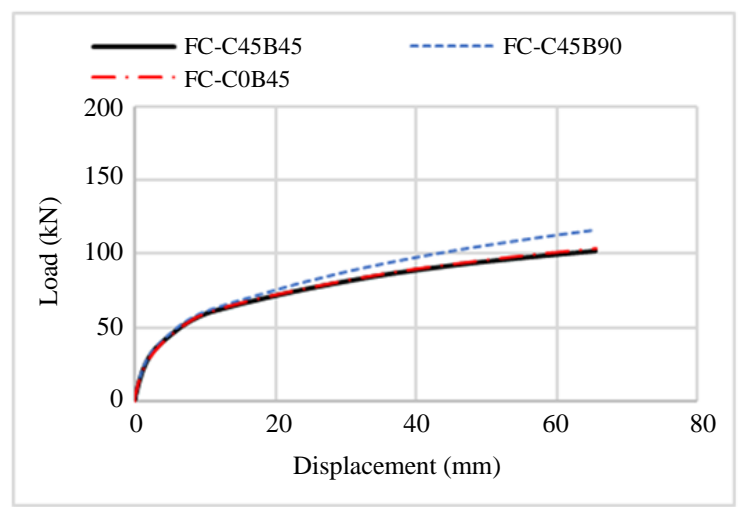

(c)

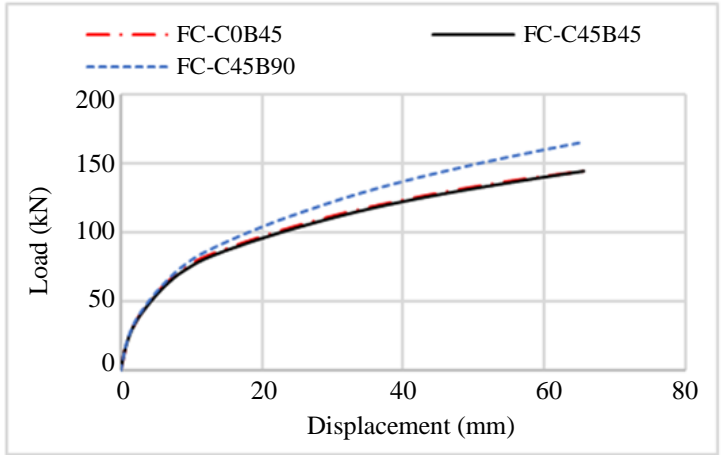

(b)

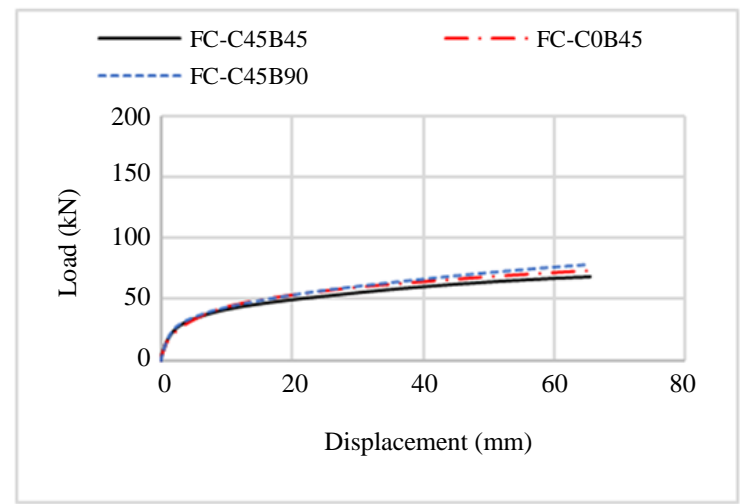

(d) 


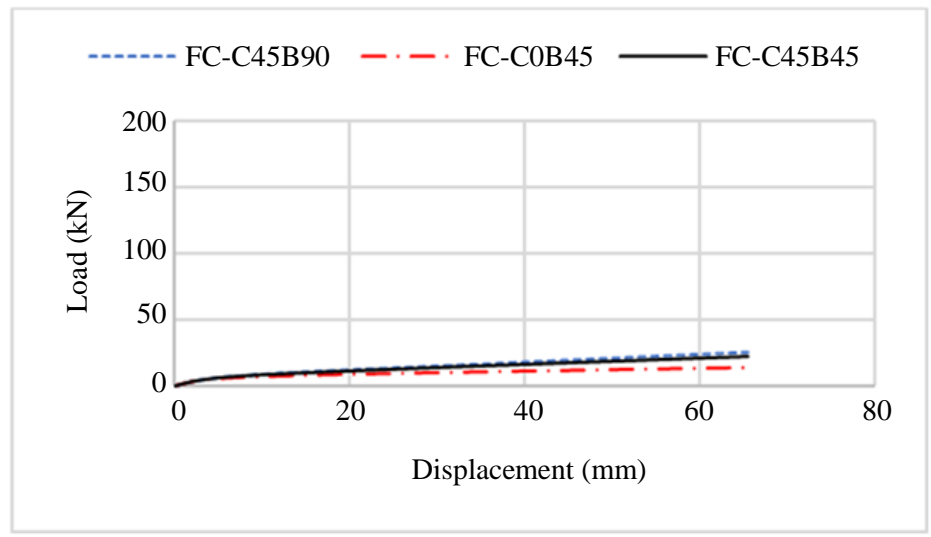

(e)

Fig. 14: Load displacement diagram for model with CFRP sheet under (a) $200^{\circ} \mathrm{C} \mathrm{(b)} 400^{\circ} \mathrm{C}$ (c) $600^{\circ} \mathrm{C}(\mathrm{d}) 800^{\circ} \mathrm{C}$ (e) $1000^{\circ} \mathrm{C}$

Table 3: Von Misses Stress - F-CbTotal Under 1000 celsius degree

Von Misses of RC Frame and
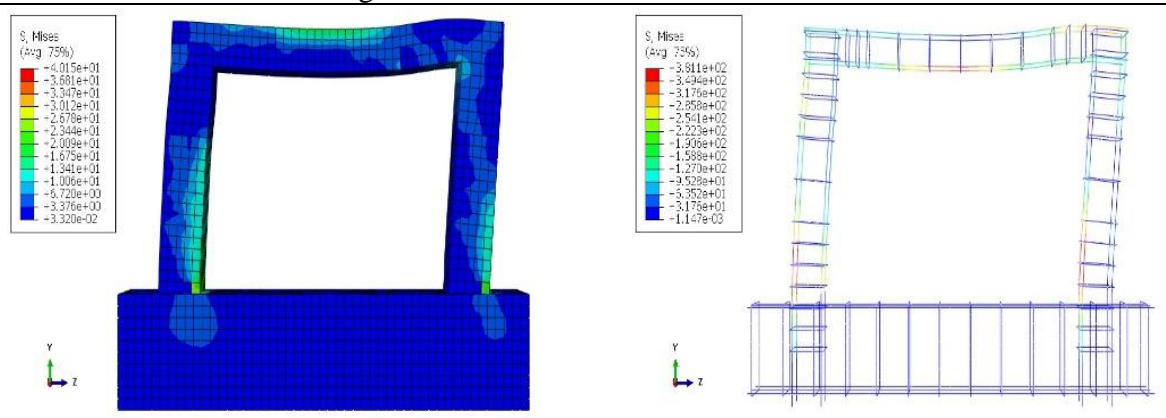

CFRP Sheets F-CbTotal Model-

Under 1000 Celsius Degree

As it is clear in Fig. 12, by increasing the fire temperature, the load capacity is reduced, so that it has significant reduction in load capacity for models of $\mathrm{M}$ 800 and M-1000. By looking at the model M-1000, the maximum displacement is about $47 \mathrm{~mm}$ due to high temperature. In other word, in higher temperature not only the load capacity is reduced but also it causes remarkable deduction in displacement. In Fig. 13 the Von Misses and temperature stress distribution of M-200 and M-1000 is shown. In Fig. 13a, the plastic hinge is occurred at the bottom sides of columns. This figure also shows that the buckling of longitudinal bars.

On the other hand, in Fig. 13b, the stress distribution of the beam's reinforcements is over the yield and buckling happened. The stress and temperature distribution in Fig. 13b also show that the most area of beam and columns show as plastic characteristic due to high fire temperature which causes un-stability of RC frame. Furthermore, Table 3 shows the von misses stress of models under selected fire loading. Table 3 depicts the behavior of F-CbTotal models under fire temperature loading conditions. These strengthened models are strong enough so that the $\mathrm{RC}$ frame is stable even for $1000^{\circ} \mathrm{C}$.
In Fig. 14, the load displacement diagrams of retrofitted models by CFRP sheets is shown. The information for the name of models is shown in the Table. 1. In these figures, FC-C45B90 has the higher load capacity than others. Granted these models have been analyzed under different fire temperature, but according to the maximum load capacity, they have much more load capacity than models with only steel bars. More importantly, the load capacity of retrofitted models is enhanced when the temperature increases. According to Fig. 14d, the first slope of load displacement diagram is positive compared with models without retrofitting (Fig. 12). This means that by retrofitting, the buckling of RC frame is solved due to enhancement of the load capacity.

Figure 15 shows the result of model reinforced with CFRP bars at only the beam (F-CB-Beam) and both beam-columns (F-CB-Total). In Fig. 15a, using CFRP bars do not affect the elastic zone under $200^{\circ} \mathrm{C}$ of fire. On the other hand, by contrasting the Fig. 15b-e, in higher temperatures using CFRP bars at the beam section has better performance. It has to be mentioned that, by comparing the load capacity results for F-CB-Beam in the Fig. 15b-e, one finds out that the elastic and plastic 
zones have much better capability of load and CFRP bars prevent buckling during the fire temperature procedures. Also, the models reinforced by CFRP bars in both beam and columns (F-CB-total) loaded under $200^{\circ} \mathrm{C}$ has higher load capacity (about $65 \%$ enhancement compared to model with steel bars under $200^{\circ} \mathrm{C}$ ). In the Fig. 15e, the load capacity of model with CFRP bars in the beam and columns (F-CB-total) under $1000^{\circ} \mathrm{C}$ is $44.3 \mathrm{kN}$ so that it increased about 550 percent compared with model reinforced by steel bars under $1000^{\circ} \mathrm{C}$. In addition to the mentioned models, one model has been evaluated under the extreme fire temperature loading condition $\left(1000^{\circ} \mathrm{C}\right)$. In this model, the CFRP bars have been used only and only for the tension part of the beam which is called (F-CB-Beam-Bot). The result of this

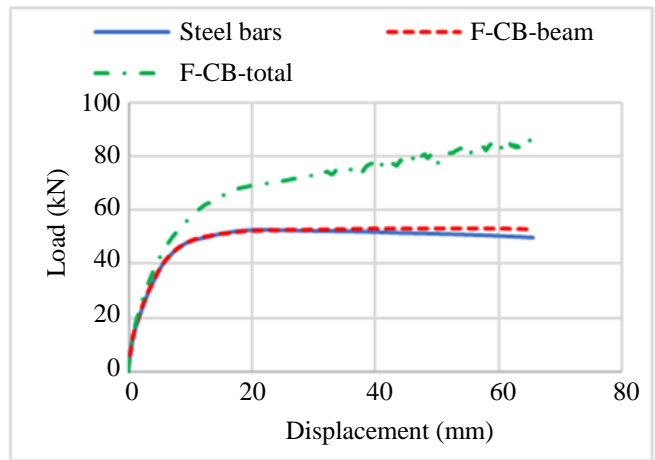

(a)

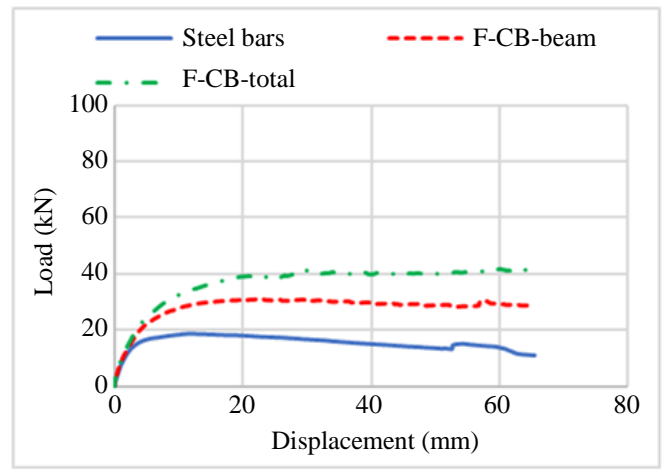

(c) model is shown in the Fig. 16 demonstrating that using CFRP bars at the tensile area of the RC beam can significantly improve the load capacity, stiffness and avoid the buckling issue of the beam.

\section{Discussion of Parametrical Study}

In this section, different results based on parametrical studies have been investigated. In this study the ductility, stiffness, load capacity and seismic factor (R) have been presented. The ductility factor is computed by dividing the maximum displacement $\left(\Delta_{u l t}\right)$ on the displacement corresponding to yield force $\left(\Delta_{y}\right)$. Equation 1 explains the ductility formulation:

$\mu=\Delta_{u l t} / \Delta_{y}$

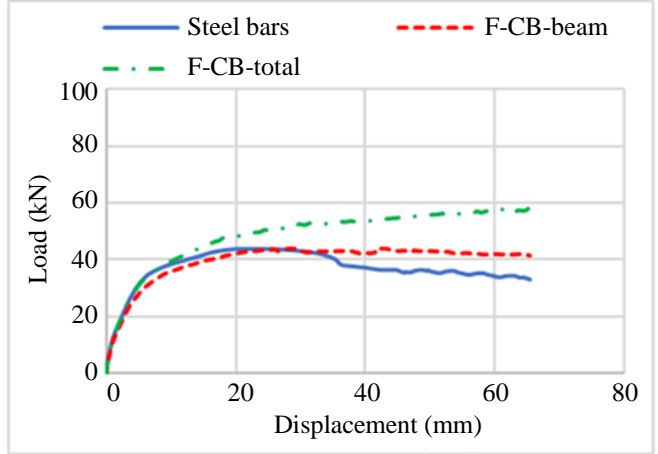

(b)

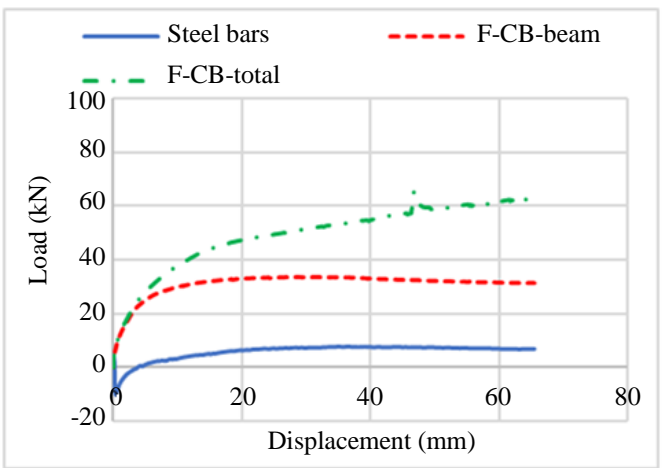

(d)

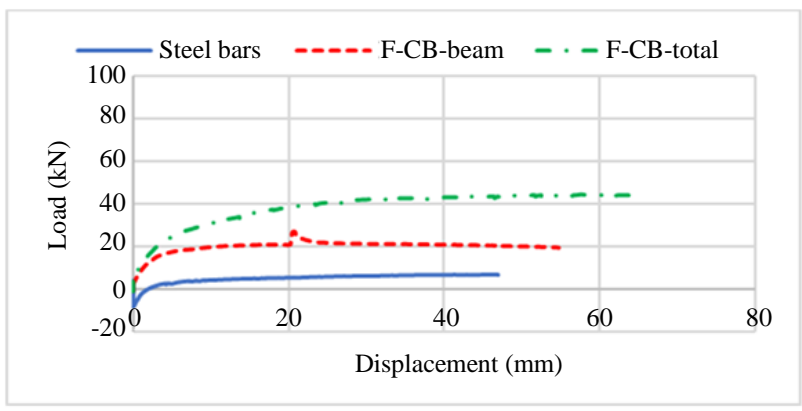

(e)

Fig. 15: Load displacement diagram for model with CFRP bars under (a) $200^{\circ} \mathrm{C}$ (b) $400^{\circ} \mathrm{C}$ (c) $600^{\circ} \mathrm{C}$ (d) $800^{\circ} \mathrm{C}$ (e) $1000^{\circ} \mathrm{C}$ 


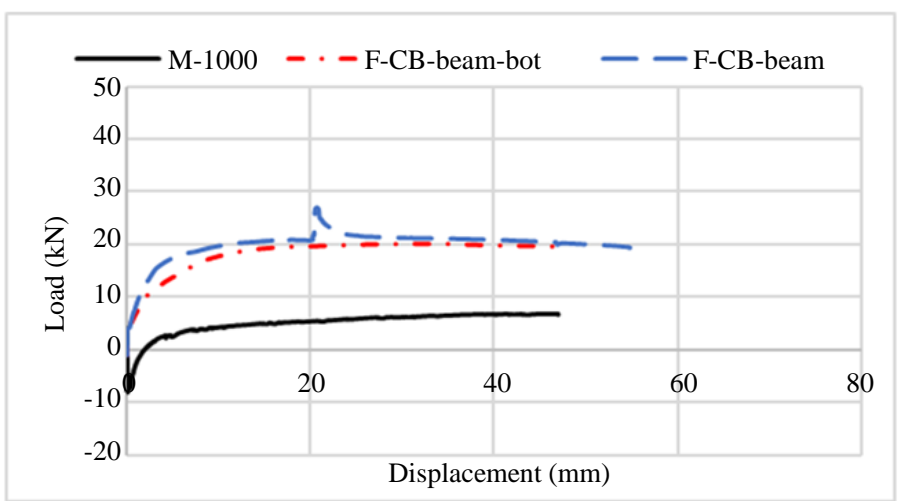

Fig. 16: Load displacement diagram for model with CFRP bars at the tensile area of the beam under 1000 Celsius Degree

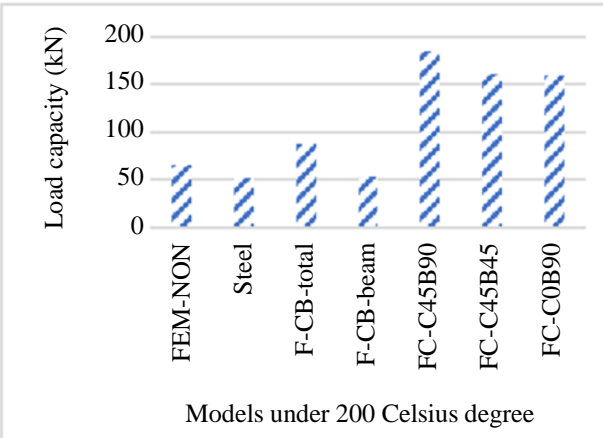

(a)

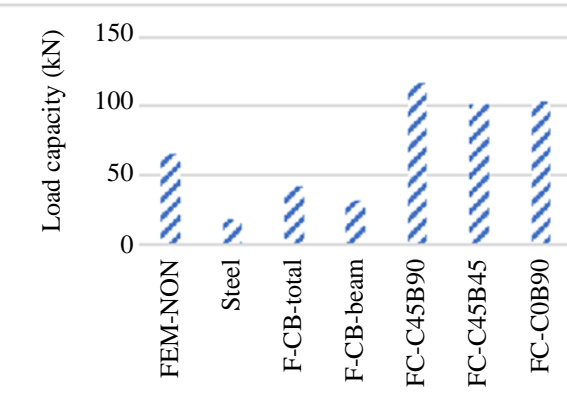

Models under 600 Celsius degree

(c)

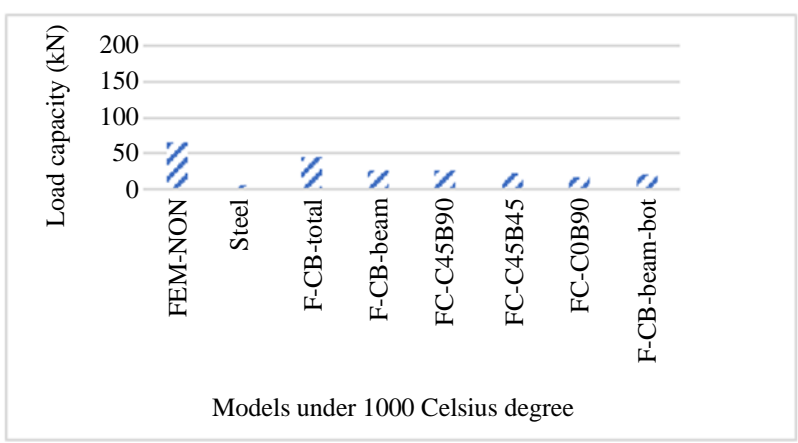

(e)

Fig. 17: Load capacity for all Models under (a) $200^{\circ} \mathrm{C}$ (b) $400^{\circ} \mathrm{C} \mathrm{(c)} 600^{\circ} \mathrm{C}$ (d) $800^{\circ} \mathrm{C}$ (e) $1000^{\circ} \mathrm{C}$ 
Also, the stiffness is calculated using load-displacement diagram as the division of yield load $\left(V_{y}\right)$. Sayyar Roudsari et al. by yield displacement $\left(\Delta_{y}\right)$, Equation 2:

$E=V_{y} / \Delta_{y}$

Eventually, the seismic factor $(\mathrm{R})$ is defined by multiplication of strength reduction factor $\left(R_{u}\right)$ by strength enhancement factor $\left(R_{s}\right)$, Equation 3:

$R=R_{u} \times R_{s}$

In the Equation (3), the strength reduction factor $\left(R_{u}\right)$ is regarding the maximum load if the structure's behavior remains in elastic zone; $\left(\left(V_{e l}\right)\right.$ over the yield load Sayyar Roudsari et al.). Equation (4):

$R_{u}=V_{e l} / V_{y}$

and, strength enhancement factor $\left(R_{s}\right)$ is computed by the yield load Sayyar Roudsari et al. divides by the load at the first plastic hinge $\left(V_{s}\right)$ :

$R_{s}=V_{y} / V_{s}$

In the Fig. 17, the load capacity of models including control (FEM-NON: Without fire temperature load), steel bars, CFRP bars and sheets under different temperature loading is shown. In these figures, the maximum load capacity under all temperature loading conditions belongs to model of FC-C45B90. Also, using CFRP sheets have more load capability than CFRP and steel bars. Moreover, the effect of RC frame by steel bars and CFRP bars just at the tensile area of the beam are almost the same for 200 and $400^{\circ} \mathrm{C}$. This issue is different for higher fire temperature. As a matter of fact, even using CFRP bars at the tensile part of concrete have good effect on the load capacity. The reason of better performance of models retrofitted by CFRP sheets is on the wake of the mechanical properties of CFRP wraps. Since it can protect the concrete surface during the fire load until rapture of the CFRP sheets. By increasing the lateral load and fire temperature, the cracks start to be propagated in the concrete which leads to complete failure. Generally, in terms of load capacity, the maximum load capacity reduction is for models under $1000^{\circ} \mathrm{C}$.

In the Fig. 18, the stiffness of all models is shown. In the Fig. 18a, the stiffness of retrofitted models is almost in the same level (about 26.67 which are under $200^{\circ} \mathrm{C}$ ) but by increasing the temperature, the stiffness of retrofitted models has been changed. In fact, in higher fire temperature load, FC-C0B90 model has better performance among retrofitted models. On the other hand, the stiffness of CFRP bars for model of F-CB-Total is higher than F-CB-Beam in all fire temperatures. The model of F-CB-Total has the best performance in the maximum fire temperature loading conditions such as 800 and $1000^{\circ} \mathrm{C}$ by having 33 and $22 \mathrm{GPa}$, respectively. In addition, the performance of models with steel bars under different loading conditions are divides into two parts. As a matter of fact, it does have a boundary as $600^{\circ} \mathrm{C}$. So that under $600^{\circ} \mathrm{C}$ the stiffness is increased but after $600^{\circ} \mathrm{C}$ degree shows a reduction trend. The reason of this issue goes back to the $\mathrm{RC}$ frame. In other word, $\mathrm{RC}$ frame tolerates both fire temperature and lateral loadings until $600^{\circ} \mathrm{C}$. After that, the steel bars start to be failed due to 800 and $1000^{\circ} \mathrm{C}$ and this issue causes buckling of the beam.

Figure 19 depicts the ductility of models. In these figures, the steel bars models have appropriate performance for 200,400 and $600^{\circ} \mathrm{C}$, but after that is has a reduction trend. Moreover, for the ductility of retrofitted models, FC-COB90 has always more value than FC-C45B45 and FC-C45B90. The steel bars models have more ductility under $600^{\circ} \mathrm{C}$ especially for 400 and $600^{\circ} \mathrm{C}$. This phenomenon occurs on the grounds of the better ductility of steel bars than CFRP bars. In fact, CFRP bars have brittle behavior and during the fire temperature (from 200 to $600^{\circ} \mathrm{C}$ and after the boundary temperature $600^{\circ} \mathrm{C}$ ), the models using steel bars start to be buckled. Therefore, the CFRP bars models have better performance in 800 and $1000^{\circ} \mathrm{C}$ loading conditions.

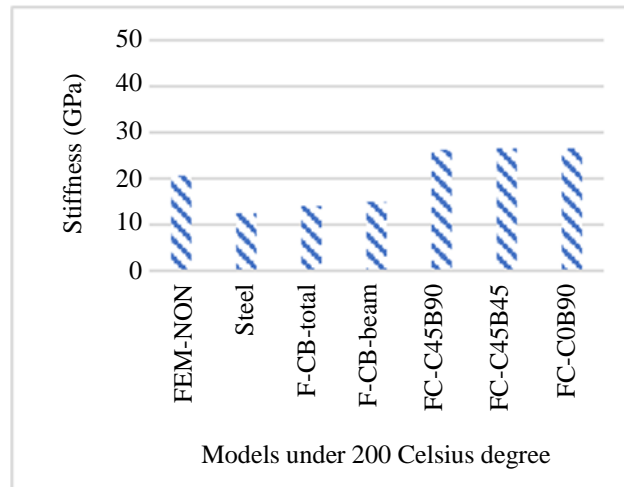

(a)

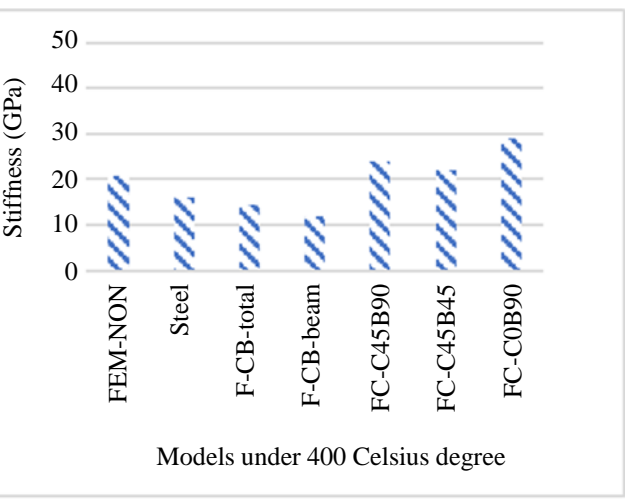

(b) 


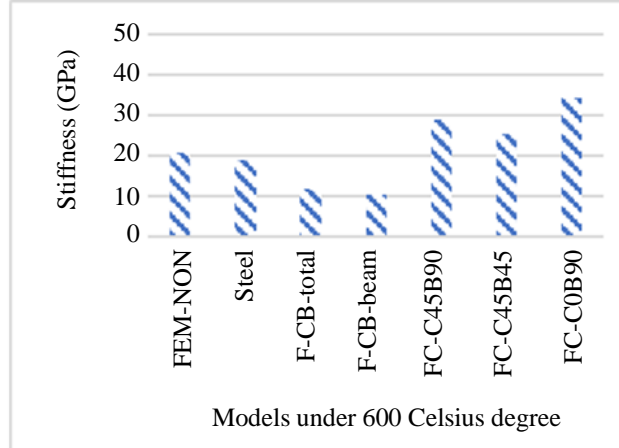

(c)

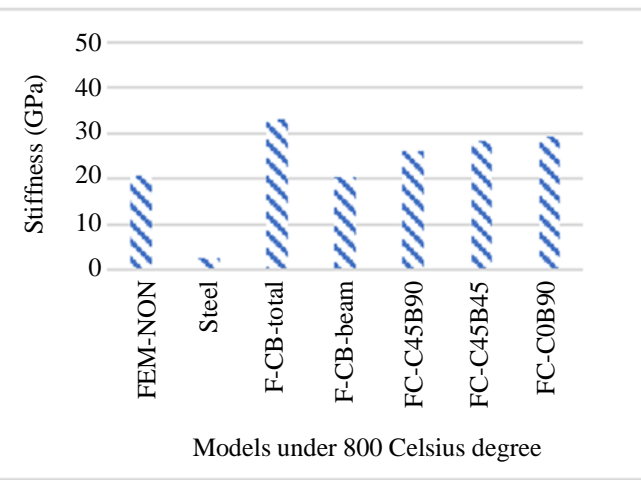

(d)

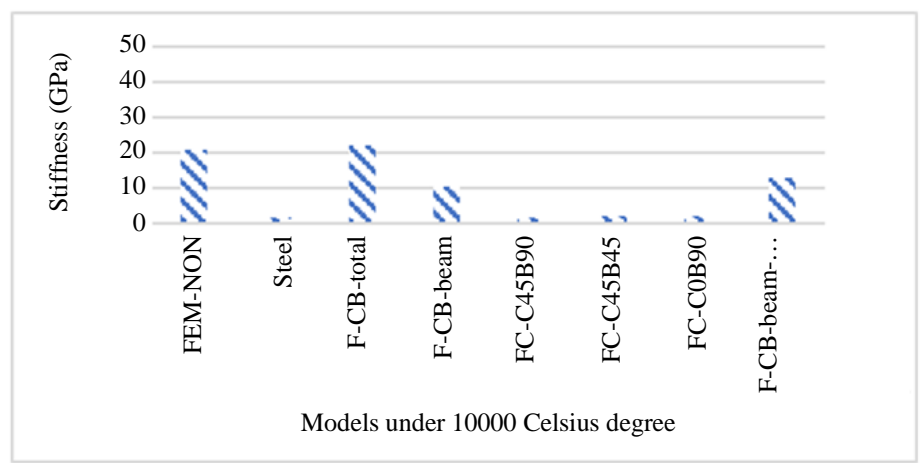

(e)

Fig. 18: Stiffness for all Models under 200 Celsius Degree

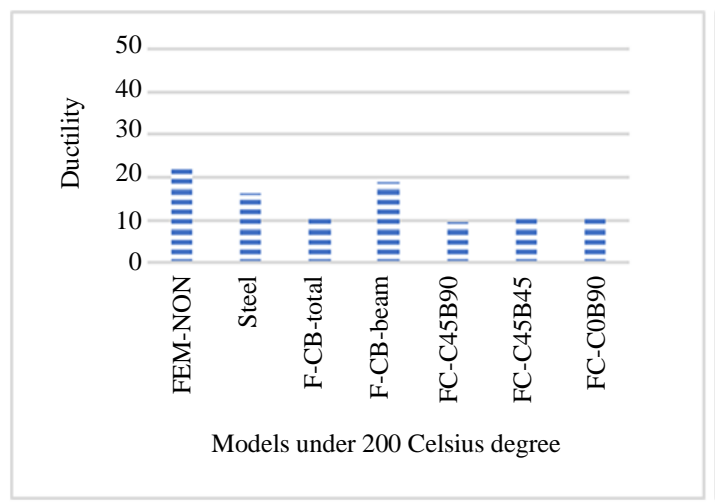

(a)

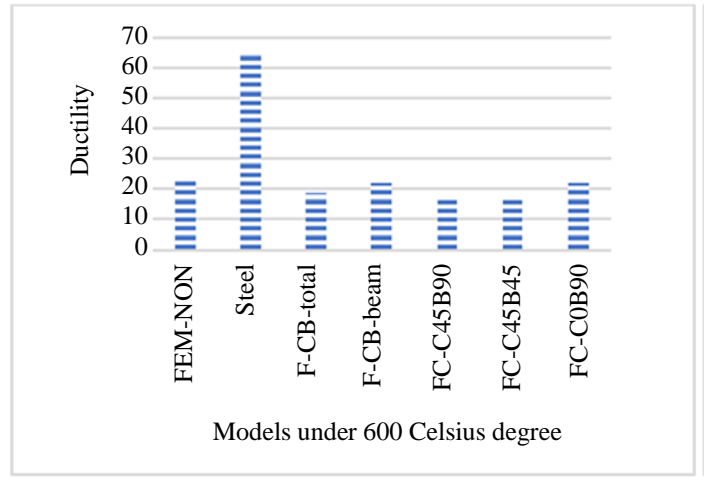

(c)

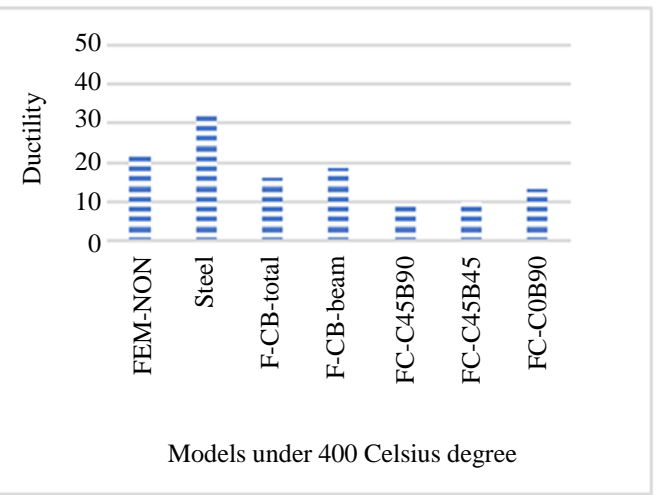

(b)

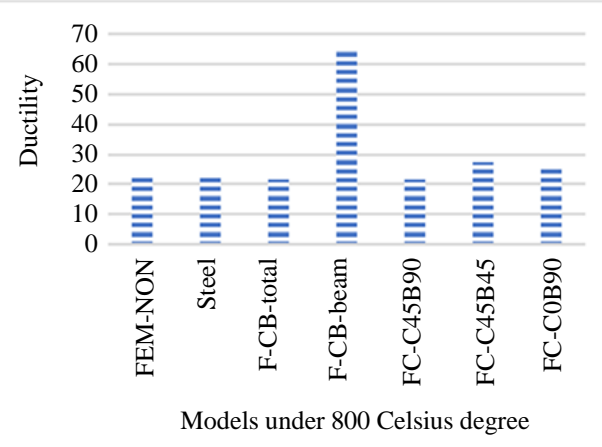

(d) 


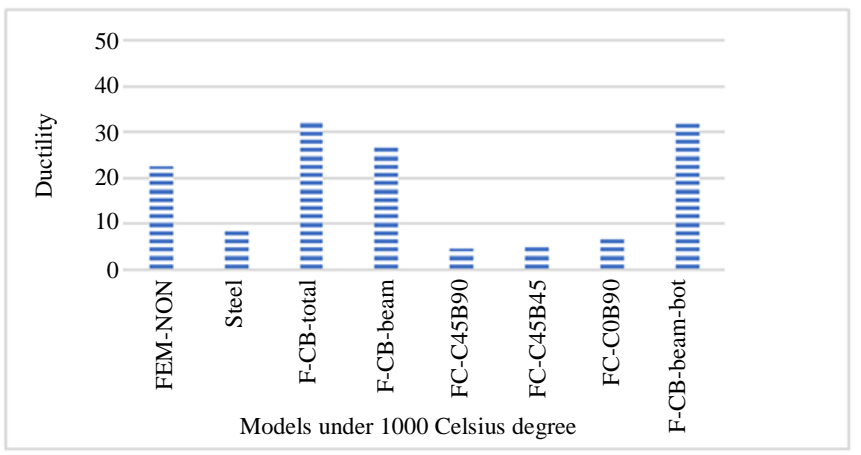

(e)

Fig. 19: Ductility for all Models under (a) $200^{\circ} \mathrm{C}$ (b) $400^{\circ} \mathrm{C}$ (c) $600^{\circ} \mathrm{C}$ (d) $800^{\circ} \mathrm{C}$ (e) $1000^{\circ} \mathrm{C}$

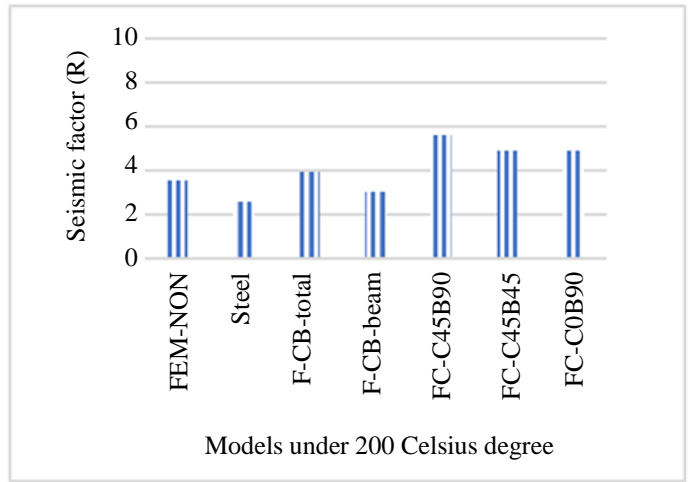

(a)

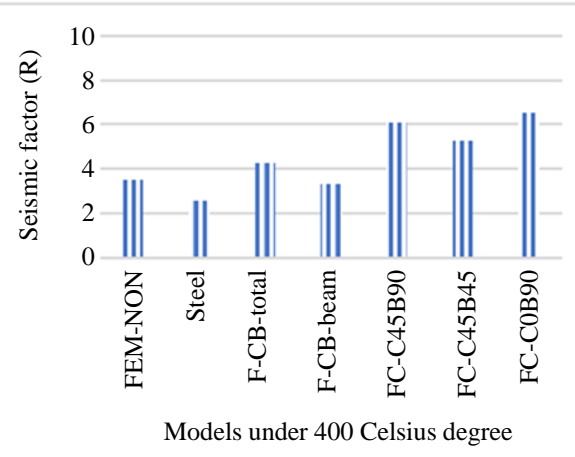

(b)

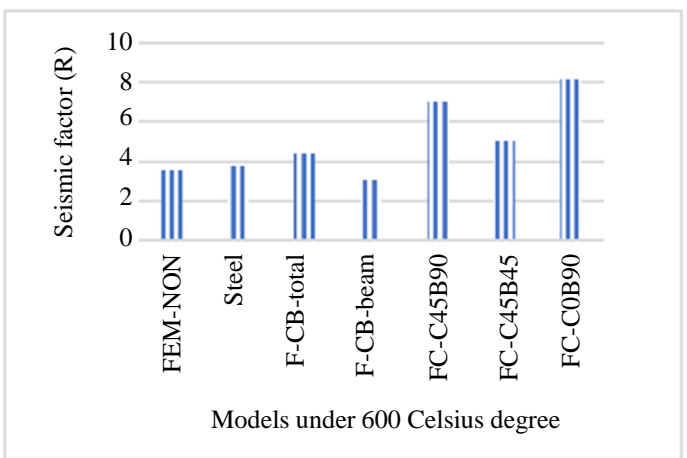

(c)

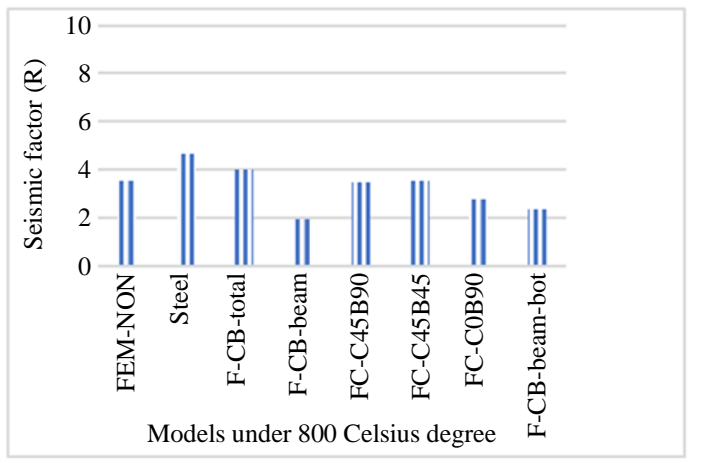

(d)

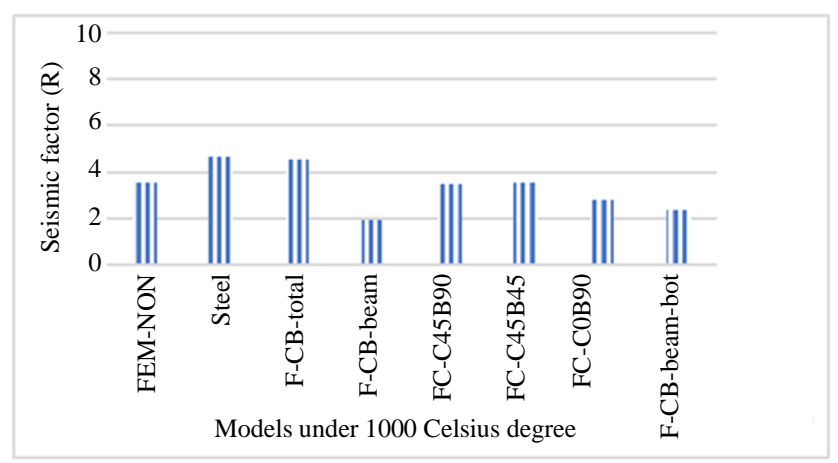

(e)

Fig. 20: Seismic factor (R)s for all models under (a) $200^{\circ} \mathrm{C}$ (b) $400^{\circ} \mathrm{C}$ (c) $600^{\circ} \mathrm{C}$ (d) $800^{\circ} \mathrm{C}$ (e) $1000^{\circ} \mathrm{C}$ 
Figure 20 shows the seismic factor of R. The R factor FC-C0B90 is higher for models under 200, 400 and $600^{\circ} \mathrm{C}$ and it has reduction trend for 800 and $1000^{\circ} \mathrm{C}$. Also, using CFRP bars at the beam has the lowest value of $\mathrm{R}$ among all models, event thought models with steel bars have increasing trend from 200 to $1000^{\circ} \mathrm{C}$.

\section{Conclusion}

On the basis of the presented modeling and analyzing and evaluated results, the followings are concluded:

- $\quad$ The maximum load capacity for 200, 400, 600 and $800^{\circ} \mathrm{C}$ is belonged to FC-C45B90 model, Fig. 17

- The boundary of fire temperature loads is $600^{\circ} \mathrm{C}$, meaning that under this degree, the models are stable and after that neither the CFRP or concrete or bars showing the failure

- The stiffness of model using CFRP bars in all members (F-CB-Total) is more than other models under $1000^{\circ} \mathrm{C}$. While the retrofitting method does not have appropriate results in improving stiffness behavior under $1000^{\circ} \mathrm{C}$, Fig. 18

- The model of FC-C0B90 shows more ductility than two other retrofitted models, especially under 800 and 1000 Celsius degrees, Fig. 19

- $\quad$ The ductility of steel bar models is increased up to $600^{\circ} \mathrm{C}$ and after that it has smooth reduction. On the other hand, the enhancing trend of CFRP bar models is increasing from 200 to $1000^{\circ} \mathrm{C}$. The important issue is that; the ductility does not affect by the boundary of fire temperature $\left(600^{\circ} \mathrm{C}\right)$, Fig. 19

- The retrofitted models have better performance of seismic factor of $\mathrm{R}$ for 200,400 and $600^{\circ} \mathrm{C}$. Particularly models of FC-C0B90 and FC-C45B90 have much more $\mathrm{R}$ value than other models in $600^{\circ} \mathrm{C}$. On the other hand, steel and F-CB-Total always have increasing trend within 200 to $1000^{\circ} \mathrm{C}$, Fig. 20

- The CFRP sheets and bars have much better performance than steel bars for avoiding the buckling and collapsing of RC frame. In effect, they can provide enough strength for system to delay the failure of $\mathrm{RC}$ frame

\section{Acknowledgment}

The Authors conducted this study is South Tehran Branch, Islamic Azad University, Tehran, Iran.

This research received no specific grant from any funding agency in the public, commercial, or not-forprofit sectors.

\section{Author's Contributions}

Reza Salehi: Performed modeling with FEM software and data analysis. Also, participated in writing the manuscript.
Abbas Akbarpour: Provided the research topic and guided the research development, experimental plan and data analysis. Also, participated in writing the manuscript.

\section{Ethics}

This article is original and contains unpublished material. Authors declare that are not ethical issues.

\section{References}

Al-Kamaki, Y. S., Al-Mahaidi, R., \& Bennetts, I. (2015). Experimental and numerical study of the behaviour of heat-damaged RC circular columns confined with CFRP fabric. Composite Structures, 133, 679-690.

Anil, Ö., \& Altin, S. (2007). An experimental study on reinforced concrete partially infilled frames. Engineering Structures, 29(3), 449-460.

ASTM, A. S. (1990). E119-88: Standard methods of fire test of building construction and materials. Philadelphia, Pa: American Society for Testing and Materials.

Baant, Z. P., Kaplan, M. F., \& Bazant, Z. P. (1996). Concrete at high temperatures: material properties and mathematical models.

Castillo, C. (1987). Effect of transient high temperature on high-strength concrete. Rice University,

Fallahi, M., Sayyar Roudari, S., Haghighifar, M., \& Madandoost, R. (2018). Modeling of reinforced concrete frames with Infill walls under cyclic loading Strengthening with CFRP. American Journal of Engineering and Applied Sciences, 11(3), 1086-1099.

Fallahi, M., Roudsari, S. S., Abu-Lebdeh, T., \& Petrescu, F. I. (2019). Investigating the effects of frp bars on the seismic behavior of reinforced concrete coupling beams. INDEPENDENT JOURNAL OF MANAGEMENT \& PRODUCTION, 10(8), 1819-1833.

Goldston, M., Remennikov, A., \& Sheikh, M. N. (2016). Experimental investigation of the behaviour of concrete beams reinforced with GFRP bars under static and impact loading. Engineering Structures, 113, 220-232.

Gyu-Yong, K., Young-Sun, K., \& Tae-Gyu, L. (2009). Mechanical properties of high-strength concrete subjected to high temperature by stressed test. Transactions of Nonferrous Metals Society of China, 19, s128-s133.

Hamoush, S., Megri, A., Pasha, R., \& Sayyar Roudsari, S. (2019). Fire Performance of Sustainable Materials Made from Renewable Sources. Paper presented at the 4th International Sustainable Buildings Symposium, Dallas, USA. 
Hemmati, A., Kheyroddin, A., Sharbatdar, M., Park, Y., \& Abolmaali, A. (2016). Ductile behavior of high performance fiber reinforced cementitious composite (HPFRCC) frames. Construction and Building Materials, 115, 681-689.

Khaliq, W., \& Kodur, V. (2011). Thermal and mechanical properties of fiber reinforced high performance selfconsolidating concrete at elevated temperatures. Cement and concrete research, 41(11), 1112-1122.

Khaliq, W., \& Kodur, V. (2013). Behavior of high strength fly ash concrete columns under fire conditions. Materials and structures, 46(5), 857-867.

Kheyroddin, A., \& Naderpour, H. (2008). Nonlinear finite element analysis of composite RC shear walls. Iranian Journal of Science and Technology, 32(B2), 79.

Kodur, V., Cheng, F. P., Wang, T. C., \& Sultan, M. (2003). Effect of strength and fiber reinforcement on fire resistance of high-strength concrete columns. Journal of structural engineering, 129(2), 253-259.

Kodur, V. K. R., \& Sultan, M. A. (1998). Structural behaviour of high strength concrete columns exposed to fire.

Maranan, G., Manalo, A., Benmokrane, B., Karunasena, W., \& Mendis, P. (2016). Behavior of concentrically loaded geopolymer-concrete circular columns reinforced longitudinally and transversely with GFRP bars. Engineering Structures, 117, 422-436.

Obaidat, Y. T., Heyden, S., \& Dahlblom, O. (2010). The effect of CFRP and CFRP/concrete interface models when modelling retrofitted RC beams with FEM. Composite structures, 92(6), 1391-1398.

Persson, B. (2004). Fire resistance of self-compacting concrete, SCC. Materials and structures, 37, 575-584.

Pham, T. M., \& Hao, H. (2016). Review of concrete structures strengthened with FRP against impact loading. Paper presented at the Structures.

Roudsari, S. S., Hamoush, S. A., Soleimani, S. M., \& Madandoust, R. (2019). Evaluation of large-size reinforced concrete columns strengthened for axial load using fiber reinforced polymers. Engineering Structures, 178, 680-693.

Roudsari, S. S., \& Abu-Lebdeh, T. M. (2019). Evaluation of Fire Effects on Reinforced Concrete Columns Using Finite Element Method. American Journal of Engineering and Applied Sciences, 12(2), 227-235.

Sayyar Roudsari, S., Hamoush, S., Soleimani, S., AbuLebdeh, T., \& HaghighiFar, M. (2018). Analytical study of reinforced concrete beams strengthened by FRP bars subjected to impact loading conditions. American Journal of Engineering and Applied Sciences, 11(2), 407-425.

Sayyar Roudsari, S., Hamoush, S., Szeto, T., \& Yi, S. (2019a). Using a 3D Computer Vision System for Inspection of Reinforced Concrete Structures. In Science and Information (pp. 608-618). Las Vegas: Springer.
Sayyar Roudsari, S., Okore-Hanson, T., Hamoush, S., Younho, S., Yi, S., Taylor, S., \& Plummer, J. (2019b). Robotic Non-destructive Test of Concrete Structures with GPR, Impact Echo and 3D Vision. Paper presented at the WM Symposia 2019 Conference, Phoenix, USA.

Sayyar Roudsari, S., Okore-Hanson;, T., Hamoush;, S. A., Sun, Y., \& Ahmed, M. (2019c). Robotic Nondestructive Evaluation of RC Structures Using 3D Vision Camera, IE and GPR. Paper presented at the American Society for Nondestrctive Testing.

Sayyar Roudsari, S., Okore-Hanson, T., Hamoush, S., Yi, S., \& Younho, S. (2020a). GPR Robotic Assisted NonDestructive Evaluation of Concrete Structures. Paper presented at the WM Symposia, Phoenix, AZ.

Sayyar Roudsari, S., Shalbaftabar, A., Abu-Lebdeh, T., Megri, A., \& Hamoush, S. (2020b). Investigation of Sandwich Panel Under High Temperature Loading Using Finite Element Analysis. American Journal of Engineering and Applied Sciences, 13(2), 318-326.

Soleimani, S. M., Boyd, A. J., Komar, A. J., \& Roudsari, S. S. (2019). Fatigue in Concrete under Low-Cycle Tensile Loading Using a Pressure-Tension Apparatus. Applied Sciences, 9(16), 3217.

Soleimani, S. M., \& Sayyar Roudsari, S. (2015). Analytical study of reinforced concrete beams tested under impact loading. Paper presented at the Proceedings of the 4th International Workshop Performance Protection Strengthening Structures Under Extreme Loading, East Lansing, MI, USA,.

Soleimani, S. M., \& Sayyar Roudsari, S. (2019). Analytical Study of Reinforced Concrete Beams Tested under Quasi-Static and Impact Loadings. Applied Sciences, 9(14), 2838.

Soroushnia, S., Tafreshi, S. T., Omidinasab, F., Beheshtian, N., \& Soroushnia, S. (2011). Seismic performance of RC elevated water tanks with frame staging and exhibition damage pattern. Procedia Engineering, 14, 3076-3087.

Tan, K. H., \& Nguyen, T. T. (2013). Structural responses of reinforced concrete columns subjected to uniaxial bending and restraint at elevated temperatures. Fire safety journal, 60, 1-13.

Tang, T., \& Saadatmanesh, H. (2003). Behavior of concrete beams strengthened with fiber-reinforced polymer laminates under impact loading. Journal of composites for construction, 7(3), 209-218.

Xiao, J., Li, Z., Xie, Q., \& Shen, L. (2016). Effect of strain rate on compressive behaviour of highstrength concrete after exposure to elevated temperatures. Fire Safety Journal, 83, 25-37.

Zhang, X., Kunnath, S., \& Xiao, Y. (2017). Experimental study of reinforced concrete columns damaged by fire following an earthquake. The 2017 World Congress on Advance in Structural Engineering and Mechanics, ASEM. 